\title{
Europos saugumas: nauji iššūkiai ir bendradarbiavimo galimybès
}

\begin{abstract}
Naujos po Šaltojo karo išryškejjusios grèsmès skatina ieškoti naujų prevencinių ir gynybinių instrumentų taip pat, iš dalies keičia tarpvalstybinius santykius saugumo srityje bei ju perspektyvas. Besikeičianti saugumo aplinka neišvengiamai veika ir Europos valstybių tarpusavio santykius bei jų saugumo perspektyvas, kurias labai sudètinga įvertinti nuolat kintančiame pasaulyje.

Globaliai vykstantys sudètingi procesai, kurie veikia tiek bendrą visų, tiek individų sauguma, bei iš esmès pakitusi tarptautinè sistema verčia iš naujo ịvertinti Europos saugumo perspektyvas. Siekiant geriau suprasti Europos šalių galimybes užtikrinti saugumą savo regione bei ivertinti šiandienines europiečiu iniciatyvas, darbo objektu buvo pasirinkta po Šaltojo karo prasidejusi ir tebevykstanti naujos Europos saugumo sistemos institucionalizacija. Straipsnio tikslas - ivvertinti Europos saugumo sistemos institucionaliacijos perspektyvas ir jų poveiki regiono saugumui. Pirmojoje straipsnio dalyje apžvelgiami globalios saugumo problematikos pokyčiai po Šaltojo karo bei išskiriami pagrindiniai veiksniai, veikiantys Europos saugumą. Antra straipsnio dalis skiriama Europoje besiformuojančios regioninès saugumo sistemos analizei. Trečiojoje ir ketvirtojoje dalyse vertinamos ES bei NATO galimybės tapti efektyvios Europos saugumo sistemos pagrindu.
\end{abstract}

Europos istorija - tai nuolatiniai karai, konfliktai, taikos sutartys bei valstybių koalicijos, nuo kurių priklausė ne tik Europos valstybių, bet ir kitų žemynų likimas. Kita vertus, Europa sietina su kultūra, pažanga, vertybių sistema per amžius veikusia net tolimiausių planetos kampelių vystymąsi. Ilgą laiką Europos saugumas daugiau ar mažiau buvo tapatinamas su stabilumu ir taika pačioje Europoje. Europa buvo saugi, kai didžiosios Europos valstybės nekariavo tarpusavyje. Tačiau XX amžiaus ìvykiai privertè iš naujo įvertinti Europos saugumo perspektyvas. Visų pirma pati Europa pasidalino ị du priešiškus Rytų ir Vakarų darinius, antra, santykinai išaugo kitų regionų valstybių itaka Europos saugumui.

Šaltojo karo metais pasaulis pasidalino į dvi priešiškas stovyklas, kurių saugumą užtikrino atgrasymo politika. Suskaldytoje Europoje veikè dvi gynybinės organizacijos , o šalių saugumo identitetas buvo formuojamas priklausymo „komunistiniam“ ar „,vakarų“ blokams pagrindu. Abu blokai turëjo aiškius priešus ir aiškias 
grèsmes, kurie vertė bendradarbiauti, kovai su jais sutelkiant bendrus resursus. Šaltajam karui pasibaigus, aiškaus priešo praradimas sugriovẻ komunistinių šalių prievartos būdu suformuotą identitetą, o bipoliarios pasaulio tvarkos žlugimas iš esmès paaštrino iki tol dviejų blokų atgrasymo politikos ribojamas problemas, siejamas su technologine pažanga ir globalizacijos procesais. Saugumo problematika išsiplètè į sferas, kurios anksčiau buvo laikomos marginaliomis: tarptautine migracija, tarptautinis nusikalstamumas, ekologinių problemų globalizacija, greitai besiplečiančios ekonominės krizės, socialiniai neramumai, etniniai konfliktai, terorizmas ir t.t.

Naujai išryškejjusios grèsmès vertè ieškoti naujų prevencinių bei kovos instrumentų, kurie iš esmès keitè Šaltojo karo metais tarp valstybių nusistovejusius santykius ir jų bendradarbiavimo galimybes. Visa tai vertè susimąstyti, ar naujai besiformuojančiame pasaulyje Europa bus saugi? Globaliai vykstantys sudėtingi procesai, veikiantys tiek bendrą visų valstybių, tiek šių valstybių gyventojų atskirai saugumą bei iš esmès pakitusi tarptautinè sistema verčia iš naujo įvertinti Europos saugumo perspektyvas. Siekiant tiksliau numatyti Europos šalių galimybes užtikrinti saugumą regione bei išanalizuoti šiandienines europiečių iniciatyvas saugumo srityje, darbo objektu buvo pasirinkta po Šaltojo karo prasidejjusi ir tebevykstanti naujos Europos saugumo sistemos institucionalizacija.

Su Europos saugumo tyrimais sietinos dvi problemos - tai nagrinëjamos saugumo problematikos ribų nustatymo problema bei vieningo Europos apibrěžimo trūkumas.

Saugumo analize - tai bandymas atsakyti į tris pagrindinius klausimus: ką saugome, nuo ko saugome ir kaip saugome? Tai - grèsmių valdymo bei karinių pajègu naudojimo ir kontrolès studijos. Klasikinis saugumo apibrèžimas teigia, kad saugumas - tai tiesioginès karinès grésmės šalies suverenumui bei teritoriniam integralumui nebuvimas. Siandieninė saugumo samprata yra daug platesnè už tradicinę klasikinę ir saugumą apibrěžia, kaip grèsmès esamoms vertybèms nebuvimą. Vis dèlto dẻl straipsnio apimties apribojimų straipsnyje koncentruojamasi ties saugumo aspektais, susijusiais su tiesioginės prievartos nebuvimu kaip pagrindine gintina vertybe.

Atsakymas ị pirmą klausimą, ką saugome, sietinas su analizės lygmens pasirinkimu. Dažniausiai sutinkama saugumo analizės schema jungia penkių lygmenų studijas: tarptautinių sistemų, tarptautinių subsistemų, junginių, subjunginių bei individu $^{1}$. Nuo pasirinkto saugumo lygmens priklauso, kokio saugumo darinio vertybių saugumas nagrinėjamas. Pažymètina tai, kad saugumo lygmenys vis dažniau tarpusavyje susipina, o ịvykiai, kurie vyksta globaliu mastu, neišvengiamai veikia regionų bei vienetų saugumą (ir atvirkščiai). Taigi nors pasirinktas straipsnio objektas sąlygoja koncentravimąsi ties Europos kaip regiono saugumu, verta pažymėti, kad tiek dẻl augančios valstybių tarpusavio priklausomybès bei kitų globalizacinių procesų, tiek dèl ilgalaikių Europos ir JAV „ypatingų ryšių“ saugumo srityje, Europos saugumo analizè išimtinai regioniniame kontekste yra nevisavertè. Todèl straipsnyje taip pat apžvelgiamos globalaus saugumo tendencijos bei jų poveikis Europos regiono saugumui.

Brěžiant tiriamo regiono ribas, būtina atsižvelgti ị tai, kad Europos regionas nevienareikšmis. Istoriniai, kultūriniai, politiniai ir instituciniai faktoriai dažnai nule-

\footnotetext{
${ }^{1}$ Buzan B., Waever O., de Wilde J., Security: a New Framework for Analysis, Lynne Riener
} Publishers Inc. 1988, 6. 
mia skirtingą Europos regiono ribų suvokimą. Jeigu kalbame apie Europą nuo Vankuverio iki Vladivostoko, ją įivivaizduojame kaip Europos saugumo ir bendradarbiavimo organizaciją (ESBO). Naudojant geografinį kriterijų, galima teigti, kad Europą riboja iš vienos pusès - Atlanto vandenynas, iš kitos - Uralo kalnai. Politine prasme, Europa dažniausiai identifikuojama su pagarba žmogaus teisèms, demokratija bei laisva rinka. Šio identiteto ribos - tai Europos Sajungos (ES) ir Šiaurès Atlanto sutarties organizacijos (NATO) valstybių sienos. Straipsnyje naudojamas politinis Europos ribų apibrèžimas, nepamirštant šalių, dalyvaujančių šiu organizacijų plètros procesuose. Valstybès, kurios bent jau artimiausiu metu netaps ES ir NATO naremis, bet kurių saugumas neatsiejamas nuo bendro Europos saugumo, ir atvirkščiai, taip pat ịtraukiamos į analizės lauką.

Straipsnio tikslas - icvertinti naujos Europos saugumo sistemos institucionalizavimo perspektyvas ir galimą įtaką regiono saugumui. Pirmojoje straipsnio dalyje apžvelgiami globalios saugumo problematikos pokyčiai po Šaltojo karo bei išskiriami pagrindiniai veiksniai, veikiantys Europos saugumą. Antra straipsnio dalis skiriama Europoje besiformuojančios regioninès saugumo sistemos analizei. Trečiojoje ir ketvirtojoje dalyje vertinamos ES bei NATO galimybès tapti efektyvios Europos saugumo sistemos pagrindu.

\section{Globalių tarptautinès sistemos tendencijų poveikis Europos saugumui}

Pasaulis po Šaltojo karo tapo chaotišku dariniu, kuris vystosi neaiškia kryptimi. Jame sunku suprasti, kas draugas, o kas priešas, su kuo reikia bendrauti, o ko reikia bijoti ir saugotis. Pasibaigus Šaltajam karui, tarptautinių santykių tyrinėtojams nepavyko sutarti dèl svarbiausių naujai besiformuojančio pasaulio bruožų, nors jie visi pripažino, kad pakito beveik visos tarptautinès sistemos ${ }^{2}$ kategorijos: sąveikų pajëgumas ir intensyvumas, procesai, vienetai ir struktūra ${ }^{3}$. Po $2001 \mathrm{~m}$. rugséjo $11 \mathrm{~d}$. pasirodè straipsnių ${ }^{4}$, kurie tvirtino, kad vèl formuojasi nauja pasaulio tvarka ${ }^{5}$, tačiau, ko gero, labiau tikètina, kad teroristiniai išpuoliai tik paskatino po Šaltojo karo (ar net Šaltojo karo metais) prasidejjusius ir tebevykstančius procesus. O šie procesai tai ilgai užsitęsęs èjimas link naujos pasaulio tvarkos, kuri dèl daugybès įvairiomis kryptimis sąveikaujančių veiksnių vis dar neịgauna aiškių kontūrų. Verta atkreipti dèmesị i keletą ypatingai svarbių tarptautinès aplinkos bei tarpvalstybinių santykių tendenciju, kurios neabejotinai veiks naujos pasaulio tvarkos formą, sąlygos naujas valstybių roles, keis jų tarpusavio santykius ir veiks saugumą tiek tarptautiniu, tiek nacionaliniu lygiu.

\footnotetext{
2 Tarptautinė sistema - tai tarptautiniame lygmenyje egzistuojančių tarptautinių santykių veikèjų sąveikų tinklas. Berridge G. R., James A. ed. A Dictionary of Diplomacy, Palgrave, N.Y., 2000, 135 .

${ }^{3}$ Buzan B., Little R., International Systems in World History: remaking the study of international relations, Oxford University Press, 2000, 3.

${ }^{4}$ Heisbourg F., „Europe and the Transformation of the World Order“, http://www.eusec.org/heisbourg/htm

${ }^{5}$ Pasaulio tvarkos pokyčiai sietini su fundamentaliai nauju požiūriu ị tai, kaip turi vykti tarptautiniai santykiai, jų filosofiniu pagrindimu bei naujomis šiuos santykius reguliuojančiomis taisyklemis.

Davies J. L. The Future of Our New World Order http://www.civic.webs.com/Cwvbib/now/article_1/now_1_definition.html
} 
Pirma, spartejja globalizacija ir daugejja valstybių sienų nepaisančių nevalstybinių veikèjų, kurie ịgauna vis daugiau galių ir veikia ypač glaudžiais saitais susipynusiose, bet taip pat labai pažeidžiamose poindustrinėse visuomenėse. Nors globalizacija ilgą laiką buvo vertinama kaip taikos ir pažangos šaltinis pasaulyje, kuriame gausu smurto ir prievartos, paaiškejjo, kad ji gali iššaukti ir neigiamų pasekmių. Globalizacijos procesas ne visus veikè vienodai: vieniems jis reiškẻ ekonominę gerovę, mokslo ir technikos pažangą, saugumą ir t.t., kitiems atvirkščiai - skurdą, ligas bei autoritarinių režimų prievartą. Pasaulis pasidalijo į laimètojus ir pralaimètojus. Pralaimètojai savo nepasitenkinimą ėmé reikšti ịvairiomis destruktyviomis formomis nuo buitinio terorizmo iki masinių demonstracijų bei globalaus masto teroristinių išpuolių. Šių destruktyvių veiksmų esmè -neapykanta Vakarams, globaliu mastu diktuojantiems savo vertybių sistemas ir keičiantiems istorijos bėgyje susiformavusias bei ịprastas neišsivysčiusių šalių politines, ekonomines bei socialines sistemas. Siekdamos universaliai igyvendinti demokratizacijos idejją, demokratiškosios šalys susikūrẻ naują priešą, kuris nebuvo nei galingas, nei racionalus, tačiau sujungęs tradicines vertybes bei moderniausias technologijas tapo rimtu iššūkiu liberaliajam pasauliui. Rugsėjo 11-ąją pasaulis akis ị akị susidūrè su grèsme, kuri turëjo visiškai kitų bruožų nei tradicinès grèsmès. Šiai grèsmei buvo būdinga didesnè nei jos pobūdžiui turètų būti griaunamoji galia, neaiškumas bei neprognozuojamumas. O stipriausios valstybės kaip taikinio pasirinkimas įrodè, kad šios grèsmès plètrai nėra ribų, kad net patys stipriausi nèra nuo jos apsaugoti.

Barry Buzanas teigia, kad po Šaltojo karo formuojasi dvilypis pasaulis, kurị sudaro ekonomiškai stiprus demokratiškas centras ir ekonomiškai atsilikusi, nedemokratiška periferija. XXI a. demokratiškosios šalys susiduria su nauju iššūkiu, ar pavyks suvaldyti chaosą, kylanti periferijoje ${ }^{6}$. Centro valstybes Buzanas įvardija brandžia anarchija ${ }^{7}$. Brandžios anarchijos šalių misija - užtikrinti stabilumą ne tik centro valstybėse, bet ir periferijoje. Tik bendradarbiaujančios centro valstybès, pasitelkdamos visas moderniausias kovos priemones bei bendrus finansinius išteklius, sugebės sustabdyti postmodernių grèsmių ${ }^{8}$ plitimą. Taigi tiek centro, tiek periferijos, tiek viso pasaulio saugumą didžia dalimi lems centro valstybiu pastangos, ryžtas ir solidarumas. Šiame kontekste ypatingai išryškëja transatlantinio ryšio reikšmė, nuo kurio tamprumo neabejotinai priklausys Europos saugumas.

Antras svarbus pasaulio po Šaltojo karo bruožas - tai iki šiol neregètą pagreitị igavusi modernių technologijų plètra bei su ja susijęs erdvès ir laiko svarbos sumažèjimas. Atstumai, kurie buvo sunkiai ịveikiami, ilgai nepasiekiami dèl gamtinių kliūčių, naudojantis naujomis komunikacinèmis priemonėmis tampa visai artimi ir greitai ịveikiami. Modernių komunikacinių priemonių plètra bei susilpnèjusi tarpvalstybinių sienų kontrolè apsunkina ekonominių, politinių, finansinių, socialinių ir kitu srautu valdymą. Nekontroliuojami neigiami reiškiniai plinta ir tampa dar vienu iššǔkiu pasauliui po Šaltojo karo.

\footnotetext{
${ }^{6}$ Van Ham P., Kugler R. L., „Western Unity and the Transatlantic Security Challenge“, Marshall Center Papers, http://www.marshallcenter.org/CISS/English/Mcpapers, 41.

${ }^{7}$ Buzan B., „Security, the State, the „New World Order“ and Beyond“ in Lipschutz R. D. ed., On Security, NY: Columbia University Press, 1998, 145.

${ }^{8}$ Geroidas Tuathailas postmodernias grèsmes apibrèžia kaip naujas „globalias“ grèsmes ir pavojus, sietinus su globalizacija, informacinių priemonių tobulejimu ir plètra, Šaltojo karo pabaiga bei po modernybès triumfo iškilusiais aplinkos saugos iššūkiais. Tuathail G. „De-territorialized threats and global dangers: geopolitics and risk society“, http://www.majbill.vt.edu/geog/faculty/total/papers/newman.html
} 
Dẻl suaktyvejjusios valstybių ir kitų tarptautinių santykių subjektų sąveikos, dèl vidaus ir užsienio politikos sferų susipynimo, griežtas Šaltojo karo metų grèsmių skirstymas ị susijusias su tiesiogine karine ataka ir ị marginalines, sietinas su nekariniais saugumo aspektais, nebeatitinka tikrovès, nes šios grèsmès vis dažniau persidengia. Grėsmių kategorijos išryškẻjusios po Šaltojo karo, verčia ieškoti naujų kovos su jomis būdų, taip pat reikia iš naujo įvertinti ir pakoreguoti karines strategijas bei struktūras.

Balkanų konflikto metu tiek amerikiečiai, tiek europiečiai suprato, kad NATO pajègos nèra pritaikytos dalyvauti regioninio pobūdžio konfliktuose ${ }^{9}$. Tai patvirtino karinė operacija Afganistane. Ateities misijoms reikès kitokio pobūdžio karinių pajègų nei Šaltojo karo metais. Politikai ir kariškiai sutaria, kad naująsias misijas turès vykdyti nedidelès specialios paskirties pajègos, besinaudojančios naujausiomis technologijomis bei moderniausiomis oro pajegomis ${ }^{10}$. Naujos karinès strategijos siejamos su Revoliucija karinèse technologijose (RKT) ${ }^{11}$.

Pertvarkyti karinius pajègumus reikèjo kardinalių reformų bei didelių pinigų ir ne visos šalys buvo pasirengusios tiek mokèti. ES valstybės vengdamos didinti savo gynybos išlaidas, dar labiau išryškino jau anksčiau egzistavusị atotrūkị tarp JAV ir Europos karinių pajègumų, ypatingai modernių technologijų srityje. Auganti JAV karine galia tampa rimta kliūtimi bendrai Europos ir JAV kariniu pajęgų veiklai netgi NATO struktūrose. Netinkama kariuomenių struktūra ir ginkluotè bei nepakankamos karinės išlaidos gali ne tik komplikuoti sajungininkų bendrus veiksmus, bet taip pat susilpninti transatlantinį ryšį, kuris šiandien yra tarptautinio stabilumo pagrindas.

Besikeičianti galių pusiausvyra ir besiformuojanti nauja pasaulio tvarka neišsvengiamai pakeite tiek globalaus saugumo dienotvarkę, tiek ir Europos padètį pasaulyje bei jos saugumo perspektyvas. Saltojo karo metais Europos saugumo sistemoje veikè užslopinimo arba savarankiško paklusimo efektas ${ }^{12}$, kuris pasireiške tuo, kad Europos saugumo interesai buvo subordinuoti dominuojančios galybės (JAV) saugumo orientacijai, o JAV dislokavo regione karines pajègas. K. M. Fierke šią sąrangą apibrěže šeimos $^{13}$ terminu. Šaltojo karo metais būtent ši šeima, sutvirtinta NATO saitais, garantavo Europos saugumą. Šaltajam karui pasibaigus, vis labiau šąlantys partnerių santykiai verčia susimastyti, ar nauja pasaulio tvarka bei jos pasekmès neišardys ilgalaikès partnerystès, bei kaip tai veiks tiek Europą, tiek globalų saugumą bei stabilumą? Dèl vis gausèjančių ,ginčųu " tarp europiečių ir amerikiečių centro blokas gali tapti „,vidinių“ nesutarimų auka tada, kai vakarietiškojo identiteto vienybė yra kaip niekuomet svarbi. Siekiant ịvertinti transatlantinio ryšio galimybes, verta susipažinti su pagrindiniais europiečių bei amerikiečiu nesutarimo šaltiniais.

\footnotetext{
9 „Peacekeeping Not NATO’s Job says Cohen“, Press Advissory: Basic Publications, 16 July 1999, http://www.basicint.org/pr_natopk.html.

${ }^{10}$ Adams G., „Convergence or Divergence? The Future of the Transatlantic Defence Industry“ in Duke S., ed., Between Vision and Reality: CFSP's Progress on the Path to Maturity,. Maastricht: European Institute of Public Administration, 2000, 180.

${ }^{11}$ RKT - sofistikuotas vadovavimas, kontrolè, komunikacija, kompiuterizacija, žvalgyba, sekimas, atpažinimas, duomenų ryšiai bei tikslinio valdymo šaudmenys.

${ }_{12}$ B. Buzan, Žmonès, valstybès ir baimé: Tarptautinio saugumo studijos po Šaltojo karo, Vilnius: Eugrimas, 1998, 278.

${ }^{13}$ Fierke K. M., „Changing worlds of security“ in Critical Security Studies: Concept and Cases 8, 1997, 230.
} 
Europiečiai vis labiau nepatenkinti amerikiečių vienašališkais veiksmais tarptautinèje politikoje. Tarptautinių įsipareigojimų atsisakymas kelia pavojų daugybei ilgus metus visos pasaulio bendruomenès pastangomis kurtų tarptautinių režimų, kurie palaikẻ bent minimalią pasitikejjimo atmosferą anarchiškoje tarptautinejje aplinkoje. $\mathrm{JAV}$ vienašališkumas europiečiams reiškia tarptautinès teisès bei tvarkos, kuria remiasi Europos saugumas, eroziją. Rimtu išbandymu JAV ir ES šalių „draugystei“, o kartu ir NATO funkcionavimui gali tapti JAV kampanijos Irake pasekmės.

Svarbus testas būsimiems JAV-Europos santykiams yra JAV priešraketinès gynybos sistemos (PGS) ateitis, turèsianti neišvengiamų pasekmių tiek transatlantinio ryšio tvirtumui, tiek Europos saugumui. Ši sistema pakeis branduolinės ginkluotès balansą Europos šalių nenaudai, sukurdama europiečiams naujas pareigas ir pavojus. Be to, priešraketinès gynybos sistemos sukūrimas reikš NATO kaip branduolinio Aljanso pabaigą, dar labiau išryškinsiančią Europos ir JAV nesutarimus Aljanso struktūrose. Pagaliau dauguma Europos valstybių antibalistinių raketų sutartị laiko tarptautinio nusiginklavimo pagrindu ir baiminasi, kad PGS gali sugriauti trapų ginklų kontrolès ir neplatinimo režimą. Kita vertus, šios sistemos įdiegimas dar labiau sumažintų europiečių bei amerikiečių galimybes kartu veikti ateityje tiek palaikant saugumą globaliame lygmenyje, tiek vykdant Europos regiono gynybą. Pradèjus veikti šiai sistemai, abejotinomis taptų ES galimybès ịsijungti ị bendrą karinę koaliciją su JAV, nukreiptą, pavyzdžiui, prieš Iraką ar kitą nedemokratišką valstybę, nes Europos valstybės būtų neapsaugotos nuo priešo atsakomųjų smūgių, ịskaitant raketas su branduoliniais, cheminiais ar biologiniais užtaisais.

Nors JAV ir ES išlieka svarbiausiais partneriais ekonominèje srityje, ekonominiai ginčai tarp ES ir JAV tampa vis dažnesni. ES ekonominès galios augimas tik dar labiau išryškins šiuos nesutarimus.

Kai kurie tarptautinių santykių apžvalgininkai gilèjantị atotrūkị tarp JAV ir Europos yra linkę aiškinti skirtingu tarptautinès sistemos įvaizdžiu ${ }^{14}$, su kuriuo susiję bendradarbiavimo galimybių vertinimas, tarptautinès teisès interpretavimas, grèsmių apibrèžimas bei kovos priemonių parinkimas. Šiandieninė Europa pasisako prieš tradicinę galios sampratą bei prievartos naudojimą. Ji virsta santykinai uždaru įstatymų, taisyklių, derybų ir bendradarbiavimo pagrindu paremtu pasauliu, kuriame nèra vietos prievartai, kuriame gerbiamos žmogaus teisès ir kurio piliečiai naudojasi gerovès valstybės teikiamasi privalumais. Pasauliu, kurị Robertas Kaganas taikliai pavadino po istoriniu taikos ir klestejjimo rojumi, Kanto „amžinaja taika“15. Šiame pasaulyje nèra didelių saugumo problemų. Europiečiai gyvena (ar bent jau gyveno) saugų gyvenimą savo pasaulio viduje, tai pat nesulaukdami didelių pavojų iš išorès, nes nuo jų saugojo amerikiečių „,skydas“ NATO struktūrose. Tačiau ši ideali tvarka, puikiai veikianti Europoje, kol kas netinka likusiam pasauliui, kuriame dar gausu nedemokratiškų valstybių. Šis pasaulis gali būti tapatinamas su Hobbeso pasaulio vizija ${ }^{16}$ - anarchišku pasauliu, kur tarptautinè teisè neveiksminga, susitarimais nepasitikima, o saugumas priklauso nuo karinés galios. Taip pasauli mato amerikiečiai.

\footnotetext{
${ }^{14}$ Kagan R., „Power and Weakness“, http://www.policyreview.org/JUN02/kagan_print.html

${ }^{15}$ Ten pat.

${ }^{16}$ Ten pat.
} 
Vis dẻlto vienašališka JAV užsienio politika, ekonominio pobūdžio ginčai ir ideologinis atotrūkis nesutarimus tarp „,sajungininkių“ gali paaiškinti tik iš dalies. Kitas svarbus veiksnys, sąlygojantis skirtingas pasaulio vizijas bei skirtingus veiksmus - tai politinès ir karinès galios pokytis JAV naudai ${ }^{17}$. Karinèje srityje nuo amerikiečių stipriai atsiliekančius europiečius domina tos problemos, kurios gali būti išspręstos su jų turimais resursais, t.y. politinėmis priemonėmis bei didelių pinigų pagalba. Karinès galios asimetrija sietina ir su grèsmių pobūdžiu - silpnesnei Europai kyla mažiau ir kitokio pobūdžio grèsmių nei stipriai, globaliai veikiančiai JAV. Amerikiečiai svarbiausiomis grèsmèmis pripažįsta: masinio naikinimo ginklų plètrą, terorizmą, nestabilias valstybes. Europiečiai savo ruožtu akcentuoja tokių iššūkių kaip etniniai konfliktai, migracija, organizuotas nusikalstamumas, skurdas bei aplinkosauginès problemos reikšmę.

Tarpusavio bendradarbiavimo būtinybę, bandant suvaldyti iš nedemokratiškos periferijos kylančias grèsmes, suvokia tiek europiečiai, tiek amerikiečiai. Europiečiams JAV svarbi dèl karinio saugumo, o JAV reikalinga Europos politine ir auganti ekonominè įtaka bei europiečių nekarinio saugumo instrumentai. Taigi tikètina, kad po Šaltojo karo išryškejję nesutarimai tarp „sajungininkų“ neišardys Europos saugumui gyvybiškai svarbios transatlantinès partnerystès. O bendradarbiavimas tarp ES ir JAV saugumo srityje išliks, tačiau ir toliau bus dalijamasi funkcijomis, išnaudojant privalumus srityse, kuriose šalys turi geriausią potencialą. Jei JAV pajëgos yra geriausios, vykdant karines operacijas ore bei operacijas, kurioms būtinos modernios technologijos, tai europiečių kariniai daliniai tinka taikos palaikymo misijoms bei sausumos operacijoms.

Greitejjantys globalizacijos tempai diktuoja dar vieną išvadą - demokratiškosios šalys, formuodamos savo užsienio ir nacionalinę saugumo politiką, privalo mąstyti ir veikti globaliai. Europiečiai bus priversti keisti savo Šaltojo karo metu strategiją, padidinti įnašus į bendrą saugumą. Kita vertus, įnašai nebūtinai turi būti kariniai įsipareigojimai. $2002 \mathrm{~m}$. kovo mèn. JAV senatorius Richardas Lugaras teigè, $\mathrm{kad}$ „europiečiai sumokès didžiają dali Afganistano atstatymo sąskaitos“"18. Europiečiai vykdo nuolatinę ekonominę pagalbą bei vystymo programas Viduriniuosiuose Rytuose, Azijoje ir Afrikoje ir taip kovai su naujomis grèsmemis suteikia nekarines priemones, kurios ypač reikšmingos, siekiant užtikrinti išbaigtą saugumo ciklą. Nekarinių saugumo aspektų nuvertinimas gali lemti tai, kad išsipildys kai kurių tarptautinių santykių tyrinètojų pranašystès, teigiančios, kad Vakarus sunaikins ne civilizacijų karas, o Markso išpranašautas neturtingujjų sukilimas prieš pasaulio turtinguosius $^{19}$, ir net didžiausios karinès išlaidos nebus pakankamos numalšinti ši sukilimą.

Pasibaigus Šaltajam karui, pakito vienos iš buvusių supergalybių padètis. SSSR subyrèjo, o Rusija nors perėmè buvusios supervalstybès teises, nebeturèjo nei to paties statuso, nei galios. Vis dèlto į Rusiją vakariečiai arba centro valstybès žiūrejo su nepasitikejjimu. Rusija Vakarų demokratijoms buvo sunkiai suprantama, jos nebuvo imanoma prognozuoti, neaišku buvo, ar Rusija pasirinks bendradarbiavimą su centro valstybèmis, ar kartu su nestabiliomis šalimis (kurių tarpe yra daug Rusijos stra-

\footnotetext{
${ }^{17}$ Ten pat.

${ }^{18}$ Lugar R. G., „NATO after 9-11: Crisis or opportunity?“ March 4, 2002, http://www.senate.gov/ $\sim$ lugar/

${ }^{19}$ Lindley-French J., „Terms of Engagement: the paradox of American power and the transatlantic dilemma post-11 September“, Chaillot Paper No. 52, 2002 May, 15.
} 
teginių partnerių) kovos prieš pasaulio turtinguosius. Vertinant Rusijos galimybes bei norą bendradarbiauti su europiečiais, verta atkreipti dėmesį i kelis svarbius šiuos santykius lemiančius veiksnius. Pirma, Rusijos užsienio politiką Vakarų atžvilgiu stipriai veikẻ Rusijos kultūra, paremta antivakarietiškomis nuostatomis ${ }^{20}$. Antra, Azijoje Rusija turi daugybę rūpesčiu dęl savo geografinio dydžio ir tai skatina rusus „draugauti“" su Vakarais. Trečia, Rusijos ir ES bendradarbiavimo prielaidas veikia ir bendras potencialiu grèsmių bei panašių kovos su jomis priemonių suvokimas ${ }^{21}$. Pagrindinès grèsmès, susijusios su Rusija, šiuo metu yra tos pačios naujo tipo grèsmès. Šie pavojai aktualūs tiek ES, tiek pačiai Rusijai, o kovoti su jais efektyviai Rusija gali tik pasitelkus ES pagalbą, ypač finansinę. Taigi bendradarbiavimas su europiečiais rusams yra ne mažiau naudingas nei patiems europiečiams tiek ekonominèje, tiek politinèje ar karinëje srityse.

Akivaizdu, kad Rusijos santykiai su Vakarais saugumo srityje iš esmès pasikeitė. Rusija, kuri buvo pagrindinis grèsmės šaltinis, dabar daugelyje sričių tapo partneriu. Ji nebèra supervalstybe (nors ambicijų vèl ja tapti kai kuriuose politiniuose bei kariniuose sluoksniuose dar išliko), ji tapo regionine galybe, dar stipria kovoti su savo priešais, bet silpna ekonomiškai ir nesugebančia ịveikti problemų, susijusių su vidiniu stabilumu ir ekonomine gerove ${ }^{22}$. Ir nors ị milžiniškus ekonominius sunkumus, sąlygojančius ir karinio komplekso atsilikimą, išgyvenančią Rusiją jau nebežiūrima kaip į tiesioginę grèsmę, postmodernių grèsmių, ateinančiu iš Rusijos, pavojus išaugo. O kadangi šiandien saugumas yra nedalomas - be saugios Rusijos negali būti saugios Europos ${ }^{23}$, taigi Rusiją būtina įtraukti ị bendrą saugumo sistemą.

Negalima tvirtinti, kad pokytis Rusijos - centro valstybiu santykiuose dar labiau išryškẻjęs po $2001 \mathrm{~m}$. rugsẻjo $11 \mathrm{~d}$. yra ilgalaikis. Dauguma nestabilių valstybių yra Rusijos strateginiai sajungininkai ar prekybos partneriai ir kol kas negalima teigti, kad Rusija nuo jų visiškai atsiriboja. Vis dèlto tikètina, kad Putino „draugyste““ su Vakarais buvo ne staigus ar neapgalvotas žingsnis, o platesnès strategijos dalis, puikiai atitinkanti bendrą ekonominių bei socialinių reformų programą. Atsižvelgiant ị tai, kad sričių, kur Rusijos pagalba taps neišvengiamai reikalinga tiek JAV, tiek Europos šalims, tik daugès ${ }^{24}$, ko gero, galima būtu teigti, kad Rusija turi galimybių tapti svarbiu Europos saugumo ramsčiu.

Taigi globaliu mastu Europos saugumas iš esmès priklausys nuo bendrų centro valstybių pastangų sumažinti neigiamas globalizacijos pasekmes, centro bendradarbiavimo su periferijos valstybėmis politinejje, ekonominejje ir saugumo srityse, taip pat nuo atskirų Europos šalių, Rusijos bei JAV elgesio racionalumo ir nuoseklumo.

\footnotetext{
${ }^{20}$ MacFarlane S. N., „Russia, the West and Europe Security“, Survival, 1993 Autumn, 10.

${ }^{21}$ Тренин Д., Россия и основные интитуты безопасноти в Европе вступая в ХХХ вэк, Москва, 2000, 88.

${ }^{22}$ Kremenyuk V., „Changes in European Security Landscape: a Russian View“, http://www.eusec.org/kremenyuk.htm

${ }^{23}$ Arnswald S., "EU Enlargement and the Baltic States: the Incremental Making of New Members“ Programme of the Northern Dimension of the CFSO, vol. 7, Helsinki: The Finish Institute of International Affaires, 2000, 105.

${ }^{24}$ Trenin D, „Russia - within - Europe: working toward a new security arrangement“ http://www.eusec.org/trenin.htm
} 


\section{Regioninès Europos saugumo sistemos galimybès}

Nors saugumo lygmenys vis dažniau tarpusavyje susipina, o įvykiai, kurie vyksta globaliu mastu, neišvengiamai veikia regionų bei vienetų saugumą (ir atvirkščiai), subsisteminis (regioninis) lygmuo, ko gero, yra tinkamiausias, siekiant paaiškinti regionines bendradarbiavimo galimybes, užtikrinant Europos saugumą. Buzanas teigia, kad „Europa buvo regioninè sistema, nes tiek jos galios santykiai, tiek eskalacijos pančiai sieja valstybes į vieną visumą “25. Regioninių saugumo darinių logiką aiškinanti klasikiné saugumo kompleksu teorija ${ }^{26}$ teigia, kad kiekvienas regionas tarsi sudaro valstybių kompleksą: draugai ir priešai; potencialūs draugai ir priešai. Saugumo kompleksas gali būti apibrèžiamas kaip grupé valstybių, kurių pagrindinès saugumo sampratos, grèsmès yra taip susijusios, jog jų nacionalinio saugumo problemos negali būti išsamiai analizuojamos, kai vieną atskiriame nuo kitos ${ }^{27}$. Nors Europą sudaro kelios valstybių grupės daugiau ar mažiau susijusios viena su kita, po Šaltojo karo pasparteję integraciniai ir globalizaciniai procesai tampa svaria priežastimi, skatinančia Europą vertinti kaip daugiau ar mažiau vientisą saugumo kompleksą. Europos valstybės yra tarpusavyje susijusios istoriniais, kultūriniais, ekonominiais bei politiniais saitais ir tiesiog nebegali nebendradarbiauti, ypač kovoje su valstybių sienų nepaisančiomis bei greitai plintančiomis grèsmėmis.

Nagrinejjant Europą kaip saugumo kompleksą, verta pripažinti, kad ji nėra visiškai vienalytis darinys. Europą galima skirstyti ị Vakarų ir Vidurio ir Rytų Europą atskirai galima išskirti Balkanus, Ukrainą, Baltarusiją bei Rusiją, kaip Europos saugumo perspektyvoms ypatingai svarbų veiksnị. Kaip jau buvo minėta, straipsnyje naudojamas politinis Europos regiono apibrezžimas, įtraukiant į ES ir NATO siekiančias įsijungti (ar jau įsijungusias) VRE valstybes, Rusiją, Ukrainą ir Baltarusiją kaip svarbų Europos saugumui veiksnị ir pagaliau Balkanų valstybes kaip ypatingą atveji. Dėl neramumų šiame regione Balkanų šalis vertėtų analizuoti kaip Europos periferiją, kuri dar neatitinka visų Europos politinio apibrèžimo kriterijų (išskyrus kandidates į ES ir NATO), bet yra svarbios bendram regiono saugumui ir stabilumui. Siektina, kad ir šios šalys būtų įtrauktos į bendrą Europos saugumo sistemą, nors kol kas galbūt ne kaip pilnateisès narès. Kita vertus, dèl šiandieninių tarptautinių santykių intensyvumo Europos saugumo analizė vien regioniniame kontekste yra nevisavertè, todẻl siekiama atsižvelgti ir į globalios aplinkos poveiki Europos saugumui.

Atsakymas ị saugumo studijų antrajị klausimą - nuo ko saugome, skatina susipažinti su šiandienine saugumo problematika bei grèsmès apibrèžimu. Saugumo problemos gali būti ịvairių formų. Paprasčiausios ir akivaizdžiausios iš jų - grèsmès. Grèsmè gali būti apibrěžiama kaip pavojus, kylantis iš aiškiai identifikuojamo veikèjo, turinčio (ar bent jau kitos valstybès taip įsivaizduoja) agresyvių ketinimų ir sugebančio savo ketinimus igyvendinti ${ }^{28}$. Tokios aiškiai apibrěžiamos grèsmès valstybių vadovams leidžia pasirinkti atitinkamas kovos su jomis priemones. Tokių grèsmių šiandieniniame pasaulyje išliko nedaug. Tikras saugumas - tai ne tik aiškių karinių

\footnotetext{
${ }^{25}$ Buzan (note 10), 240.

${ }^{26}$ Buzan, Waever, de Wilde, (note 1) 11.

${ }^{27}$ Ten pat, 12.

${ }^{28}$ Tams C., „The Functions of a European Security and Defence Identity and its Institutional Form“ in Haftendorn H., Keohane R .O, Wallander C. A ., ed., Imperfect Unions: Security Institutions over Time and Space, New York: Oxford University Press, 1999, 82.
} 
grèsmių nebuvimas, bet daugybės iššūkių, susijusių su politine, ekonomine bei socialine valstybių ir jų gyventojų gerove, kuriuos labai sudètinga apibrežzti, valdymas.

Neaiškus grèsmių ar pavojų saugumui apibrěžimas komplikuoja efektyvių priemonių kovai su šiomis grèsmèmis pasirinkimą. Vis dèlto viena iš pagrindinių šiandieninio saugumo ypatybių yra ta, kad tarpusavyje susijusios valstybès nebegali atskirai kovoti su grèsmèmis, kurių nestabdo valstybių sienos ir kurios plinta žaibišku greičiu. Tik tada, kai bendradarbiaujama, įmanoma užtikrinti saugumą. $\mathrm{O}$ bendradarbiaujama tada, kai tarp valstybių vyrauja toks pats ar bent jau panašus požiūris i grèsmę, karinių pajègų naudojimą ir kontrolę ${ }^{29}$. Viena iš efektyviausių bendradarbiavimo formu - institucijos. Institucijos gali būti ịvairios: tarptautinès konvencijos, režimai bei formalios organizacijos.

Veikdamos anarchiškoje tarptautinejje aplinkoje, valstybės yra įkalintos netikrumo spąstuose ${ }^{30}$, o saugumo institucijos užtikrina skaidrumą ir tarpusavio pasitikèjimą tarp valstybių. Institucijos tampa ne tik galimybe kartu kovoti prieš grèsmes, bet turi ir drausminantị poveikị, kuris padeda išspręsti netikrumo problemą. Jos veikia valstybių strategijas, suteikdamos daugiau pasirinkimo galimybių, pakeisdamos valstybių kaštų ir naudos skales ${ }^{31}$, taip pat tampa kažkuo daugiau nei tiesiog narių resursų suma, pačios institucijos tampa svarbiu veiksniu pasaulio saugume. Tačiau siekiant pasirinkti tinkamą bendradarbiavimo formą, verta atkreipti dèmesị į tai, su kokia saugumo problema yra susiduriama: ar tai yra aiški karinè grèsmė, ar sunkiai apibrěžiamas postmodernus iššūkis?

Valstybių bendradarbiavimas saugumo srityje svarbus dèl keturių funkcijų: 1) kolektyvinès gynybos; 2) kolektyvinio saugumo; 3) saugumo palaikymo organizacijose; 4) stabilumo už organizacijos ribų užtikrinimo ${ }^{32}$. Kiekviena funkcija reikalauja skirtingų institucinių mechanizmų funkcijoms ịgyvendinti ir problemoms spręsti. Egzistuojant neatitikimui tarp institucinių galimybių ir atliekamų funkcijų, rémimasis tarptautine organizacija gali sukelti rimtas problemas saugumo srityje. Pakitusios grèsmès verčia valstybes ieškoti naujų saugumo užtikrinimo būdų, skatina reaguoti ị pasikeitusią aplinką bei ịtakingiausių narių interesus ir užsienio politikos preferencijas. O šiandieninę valstybių saugumo politiką sudaro ilgalaikis saugumo užtikrinimo ciklas, kuris jungia politinius, socialinius, ekonominius bei karinius instrumentus.

\footnotetext{
${ }^{29}$ Ten pat.

${ }^{30}$ Wallander C. A., Haftendorn H., Keohane R. O., „Introduction“ in Haftendorn H., Keohane R. O, Wallander C. A ., ed., Imperfect Unions: Security Institutions over Time and Space, New York: Oxford University Press, 1999, 3.

${ }^{31}$ Ten pat, 9.

${ }^{32}$ Tams, (note 28) 81
} 
1 pav. Saugumo politikos funkciniai matmenys

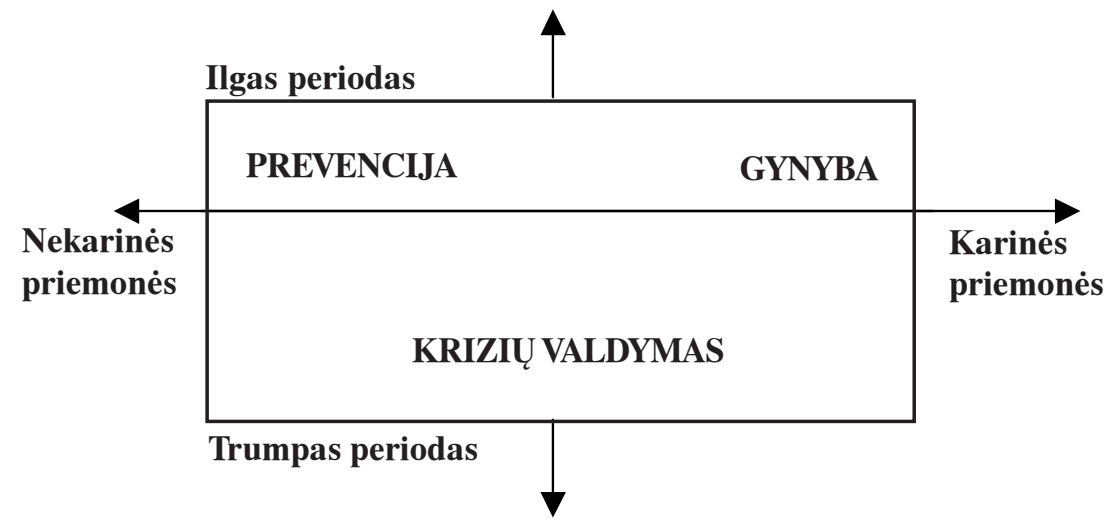

Šaltinis: Keatinge P. European Security: Ireland's choices, Institute of European Affairs, 1996, 3.

Patrickas Keatinge'as teigia, kad šiandieninį saugumo politikos ciklą geriausiai apibūdina trys saugumo politikos matmenys: prevencija, gynyba ir krizių valdymas. O šiandieninė Europos saugumo sistema galètų veikti panašiai kaip „Europos koncertas“, tačiau sudètingesne forma, kuri jungia daugiašales institucijas ir nevalstybinius veikejjus ${ }^{33}$. Jeigu veiktų idealus saugumo modelis, valstybès turètų bendradarbiauti funkcijų pasidalijimo principu, kuris užtikrintų diplomatinių, ekonominių bei karinių priemonių mastų ekonomiją bei padidintų mažujų valstybių galimybes, įsilieti ị saugumo užtikrinimo procesą.

Ilgalaikèje saugumo politikoje šiandien ypač reikšmingi prevenciniai veiksmai, sietini su „civiliniais pajëgumais“ (tarpusavio pasitikèjimo ugdymas, bendradarbiavimas ir t.t.). Gynyba arba kolektyvinè gynyba išlieka svarbia priemone kovoti su tradicinèmis grèsmèmis, tačiau vis dažniau, kai veiksmų reikia imtis nedelsiant, yra naudojami krizių valdymo instrumentai, jungiantys daug priemonių nuo tiesioginès prievartos naudojimo iki netiesioginiu „,suvaržymų“ tarptautinès organizacijose. Šiandieniniame pasaulyje svarbu išlaikyti balansą tarp visų saugumo politikos funkcinių matmenų.

Pasibaigus Šaltajam karui, buvo bandoma perbraižyti Europos saugumo struktūrų žemèlapį. Buvo pripažịstama, kad saugumo tvarka turi remtis persidengiančiomis struktūromis: ES, NATO, Vakarų Europos sajunga (VES) ir ESBO. Nedideli vaidmenys, palaikant regiono stabiluma, buvo numatyti ir Europos tarybai (ET) bei Baltijos jūros valstybių tarybai (BJVT) ${ }^{34}$. Bendradarbiaudamos tarpusavyje šios organizacijos turejo suteikti įvairaus pobūdžio saugumo užtikrinimo instrumentus, reikalingus visuose saugumo politikos matmenyse. Tačiau tai, kad nauja saugumo architektūra rẻmèsi išimtinai Šaltojo karo metais ịsteigtomis organizacijomis, kurios iš esmès buvo pritaikytos veikti visai kitomis sąlygomis bei kovoti su kito pobūdžio grèsmèmis, kèlè problemas, kovojant su naujo pobūdžio grèsmėmis.

${ }^{33}$ Keatinge P., European Security: Ireland's choices, Dublin: Institute of European Affairs, 1996, 3. ${ }^{34}$ Winn N., „Europe: Old Institutions, New Challenges" in Jones C., Kennedy-Pipe C. ed., International Security in a Global Age: Securing the Twenty - first Century, London, Portland: Frank Cass Or., 2000, 80. 
Šiandieninès Europos saugumo sistemos, jos normų, procedūrų, mechanizmų ir institucijų nepasirengimą kovoti su naujomis grèsmėmis parodè įvykiai Balkanuose ir dar kartą patvirtino $2001 \mathrm{~m}$. rugsėjo 11-osios išpuolis. Tapo akivaizdu, kad šiandien veikiančių organizacijų struktūros, tikslai ir priemonès yra netinkami XXI a. ir kad reikia ieškoti efektyvesnių institucinių formų.

Jau XX amžiaus pabaigoje pasaulio strategai pradėjo kalbèti apie naujas saugumo institucijas ir jų sistemą. Vienas iš populiariausių XXI a. saugumo sistemos modelių buvo - kooperacinio saugumo sistema. Kooperacinio saugumo sistema remiasi valstybių ar daugiašalių institucijų bendradarbiavimu ir ją sudaro keturi tarpusavyje susiję saugumo žiedai: individualusis saugumas, kolektyvinis saugumas, kolektyvinè gynyba ir stabilumo plètra ${ }^{35}$.

Individualus saugumas sietinas su žmogaus teisių apsauga sistemos viduje bei už jos ribų. Šis lygmuo tapo ypatingai reikšmingu XXI a., susidūrus su nauju tarptautinės teisès aiškinimu, kai žmogaus teisès tampa svarbesnès nei valstybių teritorinis suverenitetas. Tokios tendencijos priartina pasauli prie Kantiškosios pasaulio vizijos $^{36}$, kur taikiosios valstybės imasi prievartinių veiksmų prieš netaikias šalis, naudojančias neteisètą prievartą prieš savo piliečius.

Kolektyvinis saugumas - tai taikos ir stabilumo palaikymas bendroje erdveje. I sistemos vidų orientuotos kolektyvinio saugumo organizacijos (JT, ESBO), skiriasi nuo kolektyvinès gynybos organizacijos, kurios yra orientuotos į išorę, t.y. skirtos apsaugoti organizacijos narius nuo išorinių grèsmių. Kai kurios organizacijos jungia abu žiedus (NATO). Kolektyvinio saugumo funkcija labai svarbi kovoje su postmoderniais iššūkiais, tačiau kolektyvinės gynybos žiedas išlieka būtinas, kai kovojama su tradicinėmis grèsmėmis.

Stabilumo plètros žiedo esmè - stabilumo kituose regionuose palaikymas, naudojant politines, ekonomines ir, jei reikia, karines priemones. ES Užsienio ryšiu komisaras Christopheris Pattenas, kalbèdamas apie pasikeitusią saugumo problematiką, pastebėjo, kad „nesvarbu, kokia galinga būtų valstybè, galbūt net pati galingiausia visame pasaulyje - ji negali visko daryti pati [...], „protingosios“ bombos yra svarbios, tačiau dar svarbesnè yra protinga pagalba vystymuisi [...]. Svarbesnis yra siekis valstybes įtraukti ị tarptautinę bendruomenę nei jas išstumti“'37. Pasaulyje, kuriame vis labiau ryškejja atotrūkis tarp turtingų demokratijų ir neturtingų bei nestabilių trečiojo pasaulio valstybių, šis žiedas ịgauna ypatingą prasmę.

Šiandienis saugumas, kuris sietinas tiek su tradicinių, tiek su nauju grèsmių nebuvimu, gali būti užtikrinamas tik sujungiant visus šiuos keturis saugumo žiedus. XXI a. veiksminga saugumo organizacija turi būti pajëgi efektyviai veikti visomis ivvardintomis kryptimis.

\footnotetext{
${ }^{35}$ Cohen R., Mihalka M. Cooperative Security: New Horizonts for International Order, Garmish, Partenkirchen: George Marshall Center, 2001, 1.

${ }^{36}$ Winn (note 34), 93-94.

${ }^{37}$ Freedland J. „Patten Lays into Bush's America“, The Guardian, February 9, 2002.
} 
1 lentelè. Saugumo organizacijų galimybes sudaryti kooperacinio saugumo sistemą

\begin{tabular}{|l|l|l|l|l|}
\hline Institucija & $\begin{array}{l}\text { Individualus } \\
\text { saugumas }\end{array}$ & $\begin{array}{l}\text { Kolektyvinis } \\
\text { saugumas }\end{array}$ & $\begin{array}{l}\text { Kolektyvinė } \\
\text { gynyba }\end{array}$ & Stabilumo plètra \\
\hline JTO & Taip/ne & Taip/ne & Ne & Taip/ne \\
\hline ESBO & Taip/ne & Taip/ne & Ne & Taip/ne \\
\hline ES & Taip & Taip & Ne & Taip/ne \\
\hline NATO & Taip & Taip & Taip & Taip \\
\hline
\end{tabular}

Šaltinis: Cohen R., Mihalka M. Cooperative Security: New Horizonts for International Order, Garmish, Partenkirchen: George Marshall Center, 2001.

Europoje veikia keturios pagrindinès saugumo organizacijos: Jungtinių Tautų Organizacija (JTO), ESBO, NATO ir ES (besiformuojanti Bendra saugumo ir gynybos politika (BSGP)). İvertinus jų galimybes veikti kooperacinio saugumo sistemoje (žr. 1-ą lentelę), galima teigti, kad tik NATO turi galimybę užtikrinti priemones visuose saugumo žieduose ${ }^{38}$. Tačiau šis teiginys yra abejotinas atsižvelgiant į tai, kad visu pirma NATO buvo kuriama kaip kolektyvinés gynybos organizacija, užtikrinanti politinius, karinius saugumo instrumentus, ir, siekdama palaikyti saugumą visuose saugumo lygmenyse, ji turi keistis, antra vertus, ES vaidmuo, palaikant stabilumą ne Europoje, naudojant nekarines saugumo priemonėmis, kurios galbūt yra sunkiau pastebimos, tačiau ypatingai svarbios, siekiant užtikrinti išbaigtą saugumo politikos ciklo igyvendinimą, ko gero, yra ryškesnis nei NATO. Verta atkreipti dėmesį ir į tai, kad Maastrichto sutartis numatė ES bendros gynybos galimybę ${ }^{39}$, taigi kolektyvinès gynybos žiedas toliau vystantis Europos gynybos identitetui gali būti ịtrauktas į ES. Pagaliau susipinant 4-ojo ir 5-ojo str. grèsmèms ${ }^{40}$, gynybos sąvoka gali išsiplèsti, įtraukiant vis daugiau aspektu, sietinų su ES. Vis dèlto bent jau artimiausiu laikotarpiu ES nebus pajègi savarankiškai užtikrinti saugumo regione.

Kadangi nė viena organizacija neišpildo visų kooperacinio saugumo keliamų reikalavimų, akivaizdu, kad Europos saugumas bus palaikomas kelių daugiašalių organizacijų, kurios dirbs funkcijų pasidalijimo principu. Lentelëje galima pastebèti, kad JT bei ESBO Europos kooperacinejje saugumo sistemoje tenka tik ribotas vaidmuo. Šios organizacijos dèl politinio suderinamumo trūkumo yra pasmerktos neefektyvumui ir vykdo tik politinio forumo funkcijas. Kita vertus, būtina atkreipti dèmesi, kad operacijoms, vykstančioms už NATO ir ES ribų, legitimizuoti tarptautinès visuomenès akyse daugeliu atveju reikalingas JT mandatas. Ir nors Kosove NATO èmèsi karinių veiksmų be tokio pobūdžio mandato, toks sprendimas nèra optimalus naujoje kooperacinio saugumo sistemoje. Todèl tikètina, kad šios organizacijos išliks Europos kooperacinio saugumo sistemoje, tačiau ir toliau atliks tik ribotas funkcijas.

${ }^{38}$ Cohen, Mihalka (note 35), 16.

${ }^{39}$ Bendra užsienio ir saugumo politika (BUSP) įrauks visus klausimus, susijusius su ES saugumu, įskaitant bendros gynybos politikos formavimą, kuri per laiką gali išaugti i bendrą gynybą. Treaty of EU, Maastricht, 1991, http://europe.eu.int/eur_lex/eu/treaties/index.html

404 str.: Šalys kartu konsultuosis, jeigu kurios nors iš jų nuomone, kyla grèsmè kurios nors šalies teritoriniam vientisumui, politinei nepriklausomybei ar saugumui; 5 str.: Šalys susitaria, kad ginkluotas vienos ar daugiau šalių Europoje ar Šiaurès Amerikoje užpuolimas ịvyks, kiekviena ju igyvendindama JT chartijos 51 str. pripažintą individualios ar kolektyvinės savigynos teisę, suteiks taip užpultajai šaliai ar šalims pagalbą pati ir suderinus su kitomis šalimis imsis veiksmų, kuriuos mano esant reikalingais, įskaitant ginkluotos jëgos panaudojimą, kad Šiaurès Atlanto erdvejje būtu atstatytas ir palaikomas saugumas. Šiaurès Atlanto sutartis, Vašingtonas, 1949 m. balandžio 4 d. 
Karlas Kaiseris siūlo schemą, padedančią suvokti besiformuojančią gynybinę sistemą Europos regione ${ }^{41}$ (ši schema buvo pasiūlyta ir 1999 m. Vašingtono viršūnių susitikimo metu):

- didelio masto kariniai veiksmai - JAV vadovaujamos NATO pajègos;

- raketų ir oro pajėgų atakos, nukreiptos prieš ES šalis - Europos šalių vadovaujamos NATO pajëgos (ESGI, NATO);

- nedidelio masto karinè agresija, krizių valdymas bei kariniai veiksmai teritorijose, nepasiekiamose NATO dèl 5 str. geografinių suvaržymų - BSGP (ES).

Ir nors ši gynybos žiedo schema gali keistis, pagrindinis jos principas, kuriuo JAV ir NATO suteikiamos daugiau tradicinès gynybos funkcijos, o ES veikla ribojama nekarinėmis arba krizių valdymo bei prevencijos užduotimis, ko gero, išliks. Tikètina, kad toks darbo pasiskirstymas bus igyvendinamas ir kituose žieduose.

Vis dèlto siekiant efektyvaus ES ir NATO darbo pasidalijimo bei gerai veikiančios Europos saugumo sistemos, būtina geriau koordinuoti šių organizacijų veiksmus. Robertas Hunteris teigia, kad efektyvioje Europos saugumo sistemoje bendradarbiavimas tarp ES ir NATO turi vykti šešiose srityse: 1) operacijų planavime; 2) nenumatytų situacijų planavime; 3) gynybos bei pajègumų planavime; 4) ịsigijimo planavime; 5) Šiaurès Atlanto taryboje ir Politinio ir saugumo komiteto veikloje, itraukiant Euroatlantinès partnerystès nares; 6 ) bendrai valdant krizes ${ }^{42}$. NATO ir ES privalo vadovautis ta pačia vadovavimo, kontrolès, komunikacijų ir žvalgybos metodologija. Vertinga būtų labiau koordinuoti plètros procesus.

Europos kooperacinio saugumo sistemos sèkmę veiks ne tik ES ir NATO bendradarbiavimo efektyvumas, bet ir a) NATO modernizacijos bei plètros rezultatai, b) BSGP efektyvumas, bei c) ES plètros pasekmès ${ }^{43}$. Svarbu atkreipti dėmesị i tai, kad Europos saugumui reikšmingas valstybių bendradarbiavimas ne tik daugiašalèse institucijose, bet ir įtakingiausių valstybių veikla tarptautineje arenoje bei jų vidine evoliucija. Europos saugumą regiono viduje lems kelios valstybiu kategorijos: 1) JAV, 2) ES šalys dalyvaujančios NATO ar BSGP, bei 3) valstybės, kurių kol kas negalima integruoti i NATO bei ES (kai kurios Balkanų šalys, Baltarusija, Rusija ir Ukraina). Svarbiausios valstybės išvardintose kategorijose -JAV, Didžioji Britanija, Prancūzija, Vokietija bei Rusija. Nors Rusija ne visada pripažistama Europos dalimi, tačiau ji neabejotinai patenka į tą patị saugumo kompleksa, ir tai lemia ne tik tai, kad dauguma grèsmių, kylančių Europos valstybėms yra aktualios ir Rusijai, bet ir tai, kad Europos regiono saugumą užtikrinti galima tik įtraukiant Rusiją į bendrą veiklą.

Patrickas Keatinge'as pateikia tris Europos saugumo scenarijus, priklausančius nuo trijų pagrindinių veiksnių grupių konfigūracijos (žr. 2-ą lentelę). Anot Keatinge’o, dabartinę Europos saugumo sistemą galima apibūdinti kaip pereinamojo laikotarpio ${ }^{44}$, tačiau tikètina, kad ateityje ji virs konsoliduota kooperacinio saugumo sistema.

\footnotetext{
${ }^{41}$ Kaiser K., „Challenges and Contingencies for European Defense Policy“, in Kaiser K. ed. Towards a Common Defense Policy, Paris: WEU Institute for Security Studies, 1995, 30.

${ }^{42}$ Hunter R. E., European Security and Defence Policy: NATO's companion or competitor, RAND, 2002, 158.

${ }^{43}$ Straw J., „Collective security in an enlarged Europe“, Presentatio at the conference at Intercontinental Hotel, Budapest, July 9, 2002, http:// www.Britain-info.org/defence/xq/asp/SarticleType/1/ Article_ID.2452/qx/articles_show.htm

${ }^{44}$ Keatinge (note 33$), 34$.
} 
2 lentelè. Trys Europos Saugumo sistemos scenarijai

\begin{tabular}{|c|c|c|}
\hline $\begin{array}{c}\text { Konsoliduota kooperacinio } \\
\text { saugumo sistema }\end{array}$ & $\begin{array}{c}\text { Pereinamojo laikotarpio } \\
\text { saugumo sistema }\end{array}$ & Konkuruojanti Europa \\
$\begin{array}{c}\text { Visapusiška Rusijos } \\
\text { demokratizacija }\end{array}$ & $\begin{array}{c}\text { Rusijos pereinamojo } \\
\text { laikotarpio problemos }\end{array}$ & $\begin{array}{c}\text { Rusijos revanšistinis } \\
\text { nacionalizmas }\end{array}$ \\
$\begin{array}{c}\text { ES triumviratas (Didžioji } \\
\text { Britanija, Prancūzija, }\end{array}$ & Netvirtas ES triumviratas & $\begin{array}{c}\text { Fragmentuotas ES } \\
\text { triumviratas }\end{array}$ \\
$\begin{array}{c}\text { Vokietija) } \\
\text { Glaudus daugiašalių } \\
\text { tarptautinių instituciju } \\
\text { bendradarbiavimas }\end{array}$ & $\begin{array}{c}\text { Nesuderinamumas ir } \\
\text { konkurencija tarp daugiašalių } \\
\text { tarptautinių institucijų }\end{array}$ & $\begin{array}{c}\text { Silpnos daugiašalè } \\
\text { tarptautinès institucijos, } \\
\text { vienašalès iniciatyvos }\end{array}$ \\
\hline
\end{tabular}

Šaltinis: Keatinge P., European Security: Ireland's choices, Dublin: Institute of European Affairs, 1996, 35.

Europos saugumo sistemos vystymąsi taip pat gali veikti pasaulio bendruomenès sugebëjimas likviduoti globalizacijos neigiamas pasekmes, JAV sẻkmé, kovojant su globaliais iššūkiais, Kinijos evoliucija ir dar daug kitų sunkiai numatomų veiksnių.

Kadangi šiandieniniame pasaulyje Europos saugumas neatsiejamas nuo procesų, vykstančių gretimuose regionuose, svarbu sukurti šiuolaikiškas struktūras bendradarbiavimui su kitų regionų valstybėmis, įtraukiant jas ị kooperacinio saugumo sistemą. Adamas Rotfeldas mano, kad nauja europiečių strategija turi įtraukti ir Azijos šalis (ypatingai Pakistaną, Indiją ir Kiniją) ${ }^{45}$. Vis dèlto ị ilgalaikes bendradarbiavimo struktūras galima ịjungti ne visas valstybes. Ilgalaikis bendradarbiavimas įmanomas tik tarp šalių, susietų tampriais ryšiais ir bendru identitetu, sąlygojančiu bendras taisykles, įstatymus ir bendras institucijas santykiams plètoti. Šalia visoms valstybėms bendrų interesų - užtikrinti šalies suverenitetą ir teritorinị integralumą - ilgą laiką bendradarbiaujančios valstybès turi kitų tikslų, kurie sietini su šalies piliečiais, gerove, ekonomika, ekologija, kultūra, teise bei globalesnio pobūdžio vertybèmis: pagarba žmogaus teisėms, teisinei tvarkai ir demokratijai. Šie tikslai yra kooperacinio saugumo sistemos bruožai. Nedemokratinès valstybès kooperacinio saugumo sistemoje gali dirbti kartu su demokratinèmis ir net pasiekti visai neblogų politiniu ar karinių rezultatų, o ilguoju periodu bendradarbiavimas, keisdamas interesus bei bendrą suvokimą, net gali pastūmèti nedemokratines valstybes link demokratizacijos ${ }^{46}$. Tačiau praktikoje demokratinių ir nedemokratinių šalių bendradarbiavimas dažniausiai būna trumpalaikis ir vyksta tik tol, kol tenkina abiejų pusių lūkesčius. Tikètina, kad su tomis šalimis, kurių bent jau kol kas negalima įtraukti ị kooperacinio saugumo sistemą, bendradarbiavimas vyks ad hoc koalicijose, sietinose su atsaku konkrečiai grèsmei. JAV Gynybos sekretoriaus pavaduotojas Paulas Wolfowitzas, kalbẻdamas apie tokių ad hoc koalicijų formą, pabrěžè, kad koalicijos sudètị turi diktuoti misijos pobūdis, kad negali būti vienintelẻs koalicijos skirtingoms misijoms, skirtingų misijų privalo imtis skirtingos koalicijos. Sėkmę garantuoja lanksti ir efektyvi koalicija $\mathrm{a}^{47}$.

${ }^{45}$ Rotfeld A. D., „Introduction: Global Security after 11 September 2001“, SIPRI Yearbook 2002, 10.

${ }^{46}$ Cohen, Mihalka (note 35), 38.

${ }^{47}$ Van Ham, Kugler (note 6), 10. 
Ad hoc koalicijos būtų tinkamas sprendimas ir tais atvejais, kai pavojus būna sunku numatyti ir ịvertinti, pavyzdžiui, nekontroliuojama branduolinio ginklo plètra, pilietiniai karai, gyvybiškai svarbių išteklių srautų sutrikimai, teroristiniai aktai, sabotažas ar ekologinès katastrofos. Sie pavojai gali kilti bet kuriuo momentu, bet kuriame pasaulio taške, todèl būtų labai sudètinga ir brangu kurti nuolatines institucijas kovai su jais ${ }^{48}$. Ad hoc koalicijas Europos šalys gali pradèti kurti ir tuo atveju, jei ES ir NATO struktūros nebus pritaikytos naujai saugumo problematikai. $1997 \mathrm{~m}$. ES nesugebejjo priimti sprendimo dẻl intervencijos ị Albaniją. Pagrindine kliūtimi tapo Didžiosios Britanijos ir Vokietijos nesuinteresuotumas imtis veiksmų. Italija, Prancūzija, Graikija, Rumunija, Slovenija ir Turkija (dalyvaujant Danijai, Austrijai ir, operacijos pabaigoje, Belgijai) suformavo ad hoc koalicija, kuri, bendradarbiaudama su JT ir ESBO, ívykdè operaciją Alba. Afganistano karinè kampanija buvo vykdoma, aplenkiant NATO institucines struktūras.

Regioniniame lygmenyje Europos saugumą veiks tiek šiam regionui tik iš dalies priklausančių valstybių (JAV ir Rusija) vaidmuo regioninejje saugumo sistemoje, tiek pačių europiečių tarpusavio bendradarbiavimo sėkmè. Kooperacinio saugumo sistemos efektyvumas neišvengiamai priklausys ir nuo pagrindinių Europos saugumo institucijų koordinuotos bei efektyvios veiklos, kur svarbiausi kintamieji bus NATO modernizacijos bei plètros rezultatai, ES BSGP evoliucija bei efektyvumas ir ES plètros pasekmès. Šie procesai aptariami dviejuose paskutiniuose straipsnio skyriuose.

\section{NATO modernizacija bei plètra}

Vertinant NATO galimybes dalyvauti Europos kooperacinio saugumo sistemoje, verta pripažinti, kad NATO kol kas išlieka vienintele efektyvia saugumo srityje veikiančia institucija. BSGP kol kas dar tik formuojasi, o ESBO ir JTO trūksta vieningumo, pajėgumo bei operatyvumo, sprendžiant saugumo klausimus.

Individualaus saugumo lygmenyje NATO valstybės ne tik sugeba užtikrinti savo piliečių saugumą, bet rūpinasi žmogaus teisių apsauga šalyse, kurios nepriklauso Aljansui. Siekdama sustabdyti žmogaus teisių pažeidimus Kosove, NATO vykdė karinę kampaniją, o plètodama bendradarbiavimą su nestabilių regionų šalimis, organizacija netiesiogiai jas priverčia gerbti pagrindines žmogaus teises.

Jei sutiktume su prielaida, kad liberalios demokratijos tarpusavyje nekariauja, kolektyvinio saugumo lygmuo Europos kooperacinio saugumo sistemoje galètu būti netiriamas. Kita vertus, po NATO bei ES plètros ị regionus, kuriuose demokratija dar pakankamai trapi, situacija gali pasikeisti. Kolektyvinio saugumo lygmuo gali būti akcentuojamas ir ị sistemos organizacijos struktūras nors ir nepilnateisių nariu vaidmenyse, įtraukiant Rusiją, Ukrainą ar kitas svarbias regiono valstybes, dėl objektyvių priežasčių kol kas negalinčias tapti šių organizacijų narèmis.

Kolektyvinè gynyba NATO tebeveikia pagal 5-aji Vašingtono sutarties straipsnị. Ir nors šis straipsnis buvo pritaikytas po rugsèjo 11-osios teroristinių išpuolių JAV, t.y. jau naujomis aplinkybėmis, 5 str. naudojimas ateityje gali tapti problematišku. Šiandieniniame pasaulyje vis dažniau susiduriama su postmoderniomis grèsmèmis,

\footnotetext{
${ }_{48}$ Tams (note 28), 87.
} 
kurias iš esmės apibrēžia 4-asis sutarties straipsnis. Tačiau šio straipsnio panaudojimas kolektyvinei gynybai gali tapti komplikuotu todèl, kad jame trūksta ịpareigojančios normos.

Šiaurès Atlanto bendradarbiavimo taryba (NACC) bei jos pagrindu susiformavusi Euroatlantinès partnerystės taryba (EAPC), NATO-Rusijos nuolatinè jungtinè taryba (PJC), neseniai ịkurta NATO ir Rusijos taryba, NATO ir Ukrainos komisija bei Viduržemio jūros dialogas - puikūs instituciniai pavyzdžiai, parodantys, kad NATO siekia plèsti stabilumą ir už savo ribų. Aljansas naudoja ir kitus stabilumo plètros instrumentus - krizių valdymą, Partnerystès taikos labui programą (PfP), Masinio naikinimo ginklų iniciatyvą (WMDI). Pagaliau NATO plètra pati ịrodo, kad NATO į savo veiklą siekia įtraukti vis daugiau iniciatyvų, susijusių su stabilumo plètra už Vašingtono sutarties 6-uoju straipsniu ${ }^{49}$ nustatytų organizacijos ribų. Šios iniciatyvos svarbios ir stiprinant kolektyvinio saugumo lygmeni.

Nežiūrint ị tai, kad NATO veikla apima visus saugumo žiedus ir kad ši organizacija turi puikias galimybes tapti kooperacinio saugumo sistemos pagrindu, besikeičiančioje chaotiškoje tarptautineje aplinkoje NATO susiduria su problemomis, kylančiomis dèl to, kad Šaltojo karo metais ịsteigtų organizacijų instrumentai bei struktūros neatitinka naujų saugumo politikos poreikių. Šie trūkumai privertẻ suabejoti NATO galimybėmis, užtikrinant efektyvią kovą su Europos saugumo problemomis.

1990 m. NATO Romos viršūnių susitikime buvo paskelbta, kad Europa įženge į naują erą ${ }^{50}$, o naujai Europai reikejo naujos kokybès NATO. Buvęs JAV Gynybos sekretorius Williamas Cohenas pareiškè, kad vienas iš svarbiausių šiandieninès saugumo organizacijų uždavinių - ,taikos palaikymas - nèra JAV karinių pajègų pagrindinė misija, tai nėra pagrindiné užduotis ir daugeliui NATO narių. Taikos palaikymo misijų igyvendinimas reikalauja visiškai kitokio pasirengimo bei kitokių pajègų. Karinė jẻga tokiose misijose ne visada yra optimaliausias sprendimo variantas ${ }^{\text {"51 }}$. Ar NATO pasiruošusi kovoti su naujais iššǔkiais? Pirma, neturedama taikos palaikymo instrumentų, NATO nepajėgia užtikrinti, kad būtų igyvendintas išbaigtas saugumo ciklas. Antra, NATO galimybės kovoti su dar viena svarbia šių dienų grèsmių masinio naikinimo ginklų nekontroliuojama plètra taip pat yra abejotinos. Trečia, atsižvelgiant ị tai, kad šiandieninès grèsmès dažnai yra globalaus pobūdžio reiškiniai, NATO turi būti pajègi veikti globaliai, neapsiribojant Vašingtono sutarties 5 str. apibrěžiamomis ribomis, tačiau NATO vis dar neturi teisinių galimybių veikti nuo Aljanso erdvès nutolusiose teritorijose. Teisę įsitraukti į karines operacijas ne NATO teritorijose, organizacijai gali suteikti JT mandatas, kurị gauti dažnai būna sudètinga (arba bent jau NATO veiksmai neturi prieštarauti JT pagrindiniams principams ir būti suderinami su JT chartija). Užsitęsiantys svarstymai JT sumažina operatyvaus atsako galimybes, o nevienalytė JT Saugumo tarybos sudètis it veto teisè tampa kliūtimi priimti sprendimą,

\footnotetext{
${ }^{49} 6$ str.: 5 straipsnyje ginkluotu vienos ar daugiau Šalių užpuolimu turi būti laikomas toks ginkluotas užpuolimas, kurị sudaro: 1) užpuolimas bet kurios Europos ar Šiaurès Amerikos Šalies teritorijoje, Prancūzijos, Alžyro departamentuose, Turkijos teritorijoje ar salose, esančiose bet kurios Šalies jurisdikcijoje, Šiaurès Atlanto erdveje ị šiaurę nuo Véžio atogrąžos; 2) užpuolimas bet kurios Šalies pajègų, laivu ar lèktuvų, jiems esant šiose teritorijose, ar virš jų bet kurioje Europos vietoje, kurioje buvo išdèstytos bet kurios Šalies okupacinès pajègos tą dieną, kai ịsigaliojo ši sutartis, arba Viduržemio jūroje, arba Šiaurès Atlanto erdvèje ị šiaure nuo Vėžio atogrąžos.

${ }^{50}$ NATO Press Releases, http://www.nato.int/docu/comm/49-95/c911108a.htm

${ }^{51}$ Press Advisory: Basic Publications (note 8).
} 
kai narių interesai išsiskiria. Ketvirta, vienu iš svarbiausių organizacijos trūkumų tapo netobula struktūra ${ }^{52}$, kurios trūkumai ypatingai išryškejjo Afganistano karinès kampanijos metu. Siekdama operatyvumo ir lankstumo JAV sajungininkų pajègumais naudojosi apeidama biurokratizuotas politines NATO struktūras.

Siekiant išlaikyti Aljanso gynybini pajėgumą, jau dešimtojo dešimtmečio pradžioje buvo pradėtos NATO karinių vadovavimo struktūrų bei priemonių reformos. Numatytos ịvairios reformų kryptys: mobilumo, logistikos, ilgalaikiškumo bei efektyvaus veikimo, vadovavimo, kontrolès ir informacinių sistemų srityse. Pradėtos kurti mobilios, lankstesnės greitojo reagavimo pajëgos. Europiečiams ypatingai svarbios buvo Sajungininku pajègu Europoje mobiliosios pajègos (AMF) ir Sajunginių pajègu Europoje greitojo reagavimo korpusas (ARRC). 1994 metais NATO pradejo Taikos partnerystès programą (PfP), numatančią karinị bendradarbiavimą su šalimis ne NATO narèmis. Naujo pobūdžio užduotims atlikti 1993 m. buvo patvirtintos Jungtinès specialiosios paskirties pajėgos (CJTF). Taikos palaikymui skirtas pajėgas buvo planuojama įsteigti Europos saugumo ir gynybos identiteto (ESGI) struktūrose, ginkluotiems europiečiu daliniams suteikiant civilinès administracijos, policijos, konfliktų sprendimo, rinkimų organizavimo ir stebejjimo bei žiniasklaidos stebejjimo funkcijas ${ }^{53}$. Vašingtono viršūnių susitikime buvo numatyta Gynybinių pajègumų iniciatyva (DCI), kurios tikslas - patobulinti NATO pajëgumus, pritaikant juos kriziu valdymui. O NATO viršūnių susitikime, vykusiame Prahoje 2002 m. lapkričio mėn., demesys buvo skiriamas dviems pagrindiniams klausimams: NATO misijai XXI amžiuje ir tinkamiausios struktūros naujoms užduotims igyvendinti paieškoms. Susitikime buvo akcentuota naujų vadovavimo struktūrų, geografinę atsakomybę keičiant lankstesne bei mobilesne atsakomybės forma, reikalingumas.

Veiksmai, kuriu NATO ėmèsi, siekdama prisitaikyti prie naujos saugumo problematikos, Naujoje NATO strategijos koncepcijoje buvo įvertinti pozityviai ${ }^{54}$, vis dèlto verta pripažinti, kad organizacijos perspektyvos tapti kooperacinio saugumo organizacija yra dar miglotos ir priklausys ne tik nuo tolimesnès organizacijos struktūrų reformų eigos, bet ir nuo kitų veiksnių.

Vienas iš veiksnių, kuris neabejotinai veiks organizacijos efektyvumą - tai JAV ir Europos sajungininkų santykiai. JAV ir Europos kovos su svarbiausiomis globaliomis problemomis ir grèsmèmis vizijos labai skiriasi. Dažnai amerikiečiai ir europiečiai netgi skirtingai apibrèžia problemas ir grèsmes ${ }^{55}$. Pagrindine šiu skirtumų priežastimi galima laikyti JAV ir Europos atotrūkị modernių technologijų srityje, galinčia tapti rimta kliūtimi Europos ir JAV karinių pajègų bendrai veiklai. Po Saltojo karo buvo sumažintos visų NATO šalių pajègos ir biudžetai, tačiau dell privalumų, kuriuos teikia efektyvus išlaidų paskirstymas, JAV karinių pajėgų galia nesumažèjo, tuo tarpu europiečiai labai atsilieka nuo JAV beveik visose karinių pajègu srityse. Šis atotrūkis gali tapti rimta kliūtimi sajungininkų bendriems veiksmams net ir pačioje NATO. Afganistane ryšiams su savo sajungininkais JAV naudojosi ne NATO struktūra, o dvišaliais susitarimais. Viena iš priežasčių, paskatinusių amerikiečius

\footnotetext{
${ }^{52}$ Lindley-French, (note 19), 39.

53 „ESDI: Right Debate, Wrong Conclusions“ Press Advisory: Basic Publications 8 September 2000, http://www.basicint.org.ciuunits.htm

${ }^{54}$ Howorth J., „European integration and defence: the ultimate challenge“?, Chaillot Paper No. 43, 2000 November, 27.
} 
tik minimaliai naudotis sajungininkų pagalba, buvo tai, kad sajungininkai neturèjo pakankamai pajègumų, kurių šioje operacijoje reikejo JAV. Ir nors jau dèl beveik dešimtmetį Europos šalyse vykstančių kariuomenès reformų šiandieninès Europos karinès pajègos yra didesnès ir pajègesnès nei buvo prieš keletą metų, dèl teritorinès gynybos prioritetizavimo europiečiams vis dar stinga pajėgumų kovai su naujomis grèsmèmis.

Europiečių ir amerikiečių darbo pasidalijimas Bosnijoje, kai amerikiečiai priimdavo svarbiausius sprendimus ir dalyvavo pirminèse konflikto stadijose, o europiečiai tevykdè taikos palaikymo užduotis, dažnai lyginamas su „,vakarienès gaminimu“ ir ,indų plovimu“56 ir tampa nesutarimų tarp sajungininkų priežastimi. Amerikiečiai vadina europiečius ,išsisukinètojais“ (free riders) ${ }^{57}$, europiečių netenkina amerikiečių vienašališkumas. Viena vertus, amerikiečiai yra teisūs kaltindami savo sajungininkus Europoje silpnumu, kita vertus, darbo pasidalijimas neturètų sąlygoti politinès galios asimetrijos, kur amerikiečiams yra suteikiama sprendimo prièmimo teisè globaliais klausimais, o europiečiams telieka palaikyti JAV. Kyla pavojus, kad jei nebus pertvarkyta NATO struktūra, o Aukščiausioji sajungininkų pajęgų Europoje vadavietė (SHAPE) nesudarys sąlygų europiečiams formuoti lanksčių koalicijų bei efektyviau dalyvauti, sprendžiant regiono saugumo problemas, šie gali „nusisukti“" nuo NATO, perkeliant bendradarbiavimą į ES struktūras arba formuojant $a d$ hoc koalicijas. Kita vertus, kol NATO išlieka vienintele galimybe išlaikyti europiečiams gyvybiškai svarbius JAV karinius pajègumus Europoje, toks scenarijus nebūtų naudingas europiečiams. Jei dauguma karinių operacijų ateityje vyks ad hoc koaliciju rėmuose bendradarbiaujant su JAV, NATO gali tapti daugiau politinės reikšmès organizacija. Tačiau netgi būdama politine organizacija NATO būtų reikšminga institucija, keičiant Europos strateginį žemèlapị nekarinèmis priemonėmis. Julianas Lindley-French teigia, kad, siekiant išspręsti pagrindines NATO problemas, susijusias su JAV - ES santykiais, verta visų pirma atstatyti lygiavertes ir vaisingas konsultacijas tarp Aljanso partnerių. Antra, europiečiams turi būti suteikta galimybė vadovauti ne tik išimtinai europietiškose misijose, bet ir tose, kuriose dalyvauja amerikiečiai, ir taip pertvarkyti NATO struktūras. Trečia, suderinti ES planavimo struktūras su NATO. Ketvirta, Didžioji Britanija arba Prancūzija turi imtis vadovavimo europietiškoms misijoms $^{58}$. Tik tokiu atveju Aljansas gali tapti skéčiu įvairias organizacijas atstovaujančių valstybių bendroms misijoms.

NATO modernizacijos sèkmè bei efektyvumas neabejotinai priklausys ir nuo organizacijos plètros pasekmių. Kandidačių nepasirengimas ir silpnumas pajègumų srityje gali sukelti rimtų sunkumų Aljansui. Kadangi šalys kandidatès savo karinėse strategijose vis dar akcentuoja teritorinès gynybos principo prioritetiškumą, joms ịstojus ị Aljansą problemų gali kilti apibrěžiant ir vertinant grèsmes. Šių šalių politiniam elitui gali būti labai sunku įtikinti visuomenę gynybinių strategijų perorientavimo link globalesnių uždavinių tikslingumu. Nors akivaizdu, kad nẻ viena iš naujų narių nesuteiks Aljansui reikšmingų karinių resursų, NATO plètra yra esminė Aljan-

\footnotetext{
${ }_{55}$ Van Ham, Kugler, (note 6), 20.

${ }^{56}$ Kagan, (note 14).

${ }^{57}$ Free riding - terminas, kuris naudojamas, kai norima apibrěžti piknaudžiavimą kitų teikiamomis viešosiomis gèrybėmis, vengiant dalyvavimo kaštų pasidalijime.

${ }^{58}$ Lindley-French, (note 19), 66.
} 
so strategijos dalis, siekiant suvienyti ir stabilizuoti Europa ${ }^{59}$. Bulgarijos, Estijos, Latvijos, Lietuvos, Rumunijos, Slovakijos ir Slovėnijos narystė išplès politinio stabilumo zoną Europoje, o kai kurių naujų narių (Rumunija, Bulgarija) atejimas perkels NATO infrastruktūrą arčiau probleminių regionų ${ }^{60}$, sudarant palankesnes sąlygas visomis priemonėmis kovoti su iš ten kylančiomis grèsmėmis.

Siekiant atsakyti ị klausimą, kaip toliau vystysis plètros procesas, verta atkreipti dėmesį i kelis svarbius veiksnius. Pirma, atsižvelgiant $i ̣$ tai, kad plètros apimtys tiesiogiai veiks NATO vidinę struktūrą, kurią neišvengiamai reikès reformuoti, kyla klausimas, kokios bus šių reformų pasekmès NATO efektyvumui? Jau prasidèjusios NATO vadovavimo struktūrų reformos ne visada yra vertinamos taip teigiamai, kaip Naujoje NATO Strategijos koncepcijoje. Karlas Feldmeyeris pastebejo, kad šios reformos dažnai tampa ne objektyvių poreikių patobulinti karinį efektyvumą išraiška, o politinès įtakos tarp narių persiskirstymo atspindžiu ${ }^{61}$. Dar sudètingiau numatyti reformų rezultatus ị Aljansą, įijungus naujoms narèms: kuo daugiau dalyvių įsijungs i i kovą dèl įtakos, tuo sunkiau bus pasiekti susitarimą. NATO sugebẻjimas išlaikyti dinamiškumą ir efektyvumą priklausys ne tik nuo organizacijos narių sugebejimo pertvarkyti gynybos struktūras bei užsienio ir gynybos politikas, bet nuo ekonominių perspektyvų bei socialinio ir politinio suderinamumo kandidatèse ${ }^{62}$. NATO plètra gali dar labiau paryškinti ,išsisukinèjimo“ problemą, egzistavusią visą organizacijos gyvavimo laikotarpị. Naujų narių elgesys neleidžia tikètis, kad ši problema bus greitai išspręsta. Vengrija, stodama ị NATO, įsipareigojo gynybos biudžetui skirti 1,8 procento BNP (nors bendras NATO reikalavimas buvo 2,0 procentai), o iki $2001 \mathrm{~m}$. ji, SIPRI duomenimis, pasiekè tik 1,3 procento ${ }^{63}$. Antra vertus, šie duomenys neparodo, ar lëšos buvo naudojamos efektyviai. NATO ekspertai pastebi, kad naujų NATO narių - čekų, vengrų ir lenkų - karinès pajegos yra nepakankamai finansuojamos, blogai aprūpintos ir daugeliu atveju nepasirengusios bendriems veiksmams su $\mathrm{NATO}^{64}$. Verta atkreipti demesi i i tai, kad naujosios NATO narès yra vienos iš geriausiai ekonomiškai išsivysčiusių bei labiausiai remiančių NATO vidurio ir rytų Europoje. Tikètina, kad Rumunija ar Bulgarija šioje srityje susidurs su dar didesniais sunkumais.

Po NATO ministrų susitikimo Reikjavike, vykusio 2002 m. gegužės 14-15 d., NATO ir Rusijos santykiai perèjo ị kitą lygmenị. NATO-Rusijos taryba pradèjo savo veiklą tą patị mènesį, $28 \mathrm{~d}$. Šioje Taryboje NATO narès ir Rusija bendradarbiauja kaip lygiateisès partnerès bendrų interesų srityse, išlaikant NATO prerogatyvą veikti nepriklausomai ${ }^{65}$. NATO turi visišką autonomiją kolektyvinès gynybos klausimais, o dauguma 4 str. klausimų numatyta spęsti kartu su Rusija, atsižvelgiant i jos interesus bei nuomonę. Nuo pat Tarybos ịkūrimo pastebimas Rusijos ryžtas ir noras kuo aktyviau dalyvauti jos veikloje ir tai leidžia tikètis, kad ši Taryba padès įtraukti Rusijąi

\footnotetext{
${ }^{59}$ Vershbow A., „NATO enlargement“ Department of State, Washington, file, Krakow, June 2000, http://www.nato.int/usa.ambassadors/s20000607.htm

${ }^{60}$ Rotfeld, (note 45), 9.

${ }^{61}$ Croft S., „Guaranteeing European Security?: Enlarging again“, International Affairs 78 (1), 2002, 105.

${ }^{62}$ Ten pat, 110.

${ }^{63}$ Ten pat, 105

${ }^{64}$ Lokewood Ch., Butcher T. „NATO puts plans eastward enlargement on hold.“, Daily Telegraph, 3 April 2000.

${ }^{65}$ Ministerial Meeting of the North Atlantic Council, Final Communique, Reykjavik, May 14, 2002.
} 
bendrą Europos saugumo sistemą. Rusijos įtraukimas ị NATO struktūras, be abejonès, priartina NATO prie kooperacinio saugumo organizacijai keliamų reikalavimų. Antra vertus, negalima leisti, kad Rusijos dalyvavimas NATO sprendimų prièmimo procese paverstų Aljansą neefektyvia kolektyvinio saugumo organizacija, panašia į ESBO bei Europos Tarybą, kurios nariai nesugeba priimti sprendimų net labai bendrais klausimais. Vis dèlto negalima užtikrintai tvirtinti, kad Rusijos-NATO santykių atšilimas ilgalaikis. Rusija iki šiol tiksliai neivvardijo, ko konkrečiai tikisi iš Tarybos, taigi jos dalyvavimo motyvai kol kas lieka neaiškūs. NATO plètra gali kelti problemas, susijusias su Rusijos visuomenès nepalankia nuomone plètros atžvilgiu. Rusijos saugumo ar užsienio politikų krypties pasikeitimas neabejotinai veiktų šios Tarybos veiklos (o gal net ir NATO) efektyvumą.

Apžvelgus pagrindines NATO reformų kryptis, galima teigti, kad, siekdamas prisitaikyti prie XXI a. saugumo aktualijų, Aljansas pasikeitè tiek išoriškai, tiek iš vidaus, tačiau kad taptų lanksčia, šiuolaikine kooperacinio saugumo organizacija, NATO dar turi išspręsti daug svarbių problemų. Pirma, NATO privalès tęsti struktūros reformas bei neleisti reformas panaudoti didžiųjų valstybių įtakai plèsti. Antra, organizacijos efektyvumui svarbiu gali tapti 5-ojo str. problemos sprendimas. Trečia, jei NATO narès nuspręs, kad taikos palaikymo misijos nėra Aljanso uždavinys ir paliks jas ES kompetencijoje, bendra ịvairių saugumo užtikrinimo priemonių koordinavimo struktūra būtu reikalinga. Ketvirta, NATO ateitis taip pat priklausys nuo problemų, susijusių su JAV-ES santykiais sprendimo. Penkta, sèkmingas plètros procesas, nors trumpuoju periodu galintis sąlygoti mažesnį organizacijos efektyvumą, neabejotinai praplèstų organizacijos ilgalaikes galimybes dalyvauti kooperacinio saugumo sistemoje. Ir pagaliau bendradarbiavimo struktūrų su valstybėmis ne narèmis stiprinimas sudarytų sąlygas ne tik palaikyti saugumą už organizacijos ribų, bet ir bendromis priemonèmis kovoti su globaliomis grèsmèmis.

\section{Europos Sajungos saugumo ir gynybos identiteto perspektyvos}

Ekonominės gerovės augimas, bendrų vertybių ịsigalëjimas bei tradicijų panašumas Europoje tapo svarbia priežastimi, skatinusia Europos šalis siekti gilesnès integracijos. Nuo 1986 m. užsienio politikos koordinavimas, vykęs Europos politinio bendradarbiavimo (EPB) rèmuose, Maastrichte buvo formalizuotas, sukuriant antrajį ramsti -Bendrają užsienio ir saugumo politiką (BUSP). Bendros saugumo ir gynybos politikos (BSGP) atsiradimą BUSPe galima būtų įvardinti kaip neišvengiamą būtinybę šalia jau egzistuojančių šios politikos politinių-diplomatinių bei ekonominių-komercinių priemonių įtraukti saugumo matmenį bei gynybos politikos instrumentus. Kita vertus, tai buvo tarsi atsakas amerikiečių kaltinimams dèl nepakankamo europiečiu dęmesio saugumo klausimams. Po $1998 \mathrm{~m}$. St. Malo susitikimo BSGP formavimosi procesas igavo naują pagreitį, paskatinusį ES gynybinių ir saugumo aspektų skeptikus pripažinti, kad ESGI galimybės nèra visiškai beviltiškos. 1994 m. JAV pasiūlytas BSGP (NATO struktūrose) ir $1991 \mathrm{~m}$. Maastrichte numatyta ES Bendra saugumo ir gynybos politika (BSGP), galinti išsivystyti į bendrą gynybą, po Šaltojo karo tapo Europoje besiformuojančios naujos saugumo sistemos pagrindais, o Europos Sajunga, itraukusi saugumo ir gynybos lygmeni, virto ne tik ekonominiu bloku, bet kartu ir saugumo organizacija. 
Kiolno viršūnių taryba numatė VES funkcijas įtraukti ị ES ${ }^{66}$, o Helsinkyje buvo numatytas Pagrindinis tikslas (Headline Goal) ir susitarta dèl Europos greito reagavimo pajègu (GRP), gebančių vykdyti krizių valdymo operacijas, įsteigimo. Susitarta iki 2003 m. įkurti pajègas (50 $000-60000$ karių), kurios vykdytų Petersbergo užduotis $^{67}$, krizès vietoje būtų dislokuojamos ne daugiau kaip per 60 dienų ir sugebėtų veikti ne mažiau kaip vienerius metus ${ }^{68}$. Leakene buvo paskelbta, kad šios pajègos jau yra pajėgios vykdyti kai kurias krizių valdymo operacijas ${ }^{69}$. Kopenhagos viršūnių taryba nutare visiškai perimti iš NATO taikos palaikymo funkcijas Bosnijoje ir Makedonijoje. Nors buvo tikimasi, kad GRP bus paskelbtos veiksniomis jau iki $2003 \mathrm{~m}$. pradžios, terminas buvo atidètas iki vasaros.

Besiformuojančios BSGP galimybes Europos kooperacinio saugumo sistemoje vis dar sudètinga ịvertinti. Daug veiksnių, susijusių tiek su pačios ES evoliucija, tiek su tarptautine aplinka, gali pakreipti BSGP vystymąsi viena ar kita linkme. Vis dèlto verta pripažinti, kad jau dabar ES turi bent minimalias priemones, reikalingas visuose keturiuose saugumo žieduose. ES šalys, kurių dauguma yra ir NATO narèmis, taip pat rūpinasi žmogaus teisių apsauga tiek organizacijos viduje, tiek šalyse, kurios nepriklauso organizacijai. Nuolatinė ES parama trečiojo pasaulio šalims, valstybėms, kuriose vyksta konfliktai, bei lèšos karo nuniokotų šalių atstatymui, patvirtina, kad ES aktyviai dalyvauja, užtikrinant individualujį saugumą regione ir už jo ribų. Lyginant ES su NATO, verta atkreipti dėmesị, kad ir individualaus saugumo lygmenyje tarp šių dviejų organizacijų vyksta savotiškas darbo pasidalijimas, kai NATO naudoja daugiau karines, o ES nekarines priemones.

Nors pradinėse BSGP formavimosi stadijose dar sudètinga kalbèti apie bendros gynybos galimybę, tikètina, kad, stiprëjant ES bendram identitetui, sustiprès ir gynybinis identitetas. Kita vertus, kai šiandieniniame pasaulyje vis dažniau susiduriame su postmoderniomis ne 5-ojo str. grésmėmis, kylančiomis iš regionų, nutolusių nuo Europos, gali būti, kad Europos gynybos identitetas, jei pavyks jį sukurti, suteiks efektyvesnes nei NATO saugumo užtikrinimo priemones netgi kolektyvinės gynybos prasme.

Po Šaltojo karo pripažįstama, kad saugumas - nedalomas ir jo užtikrinimas i̇manomas tik įtraukiant visus sistemos narius. Siekdama plèsti stabilumą ir saugumą už organizacijos ribų, ES vykdo ekonominės pagalbos, bendradarbiavimo bei vystymo programas su gretimų regionų šalimis. Stabilumo už regiono ribų plètra tapo ilgalaike ES strategija. Tik žlugus Sovietų sajungai, Europos Bendrijos pasirašė bendradarbiavimo sutartis su buvusiomis Sajungos respublikomis bei Varšuvos pakto šalimis $^{70}$. Politinis radikalizmas ir gausẻjanti migracija iš Šiaurès Afrikos valstybių

\footnotetext{
${ }^{66}$ Cologne European Council, Presidency Conclusions,1999, http://europe.eu.int/council/off/conclu/ index.htm

${ }^{67} 1992$ m. VES šalys pasirašė Petersbergo deklaraciją, patvirtinančią jų pasiryžimą suformuoti karinius vienetus, skirtus Petersbergo užduotims igyvendinti, kurios yra apibrěžiamos kaip: humanitarinès operacijos, gelbejjimo darbai, taikos palaikymas ir krizių valdymas, http://europe.eu.int/ seadplus/leg/en/cig/g4000p.htm

${ }^{68}$ Helsinki European Council Presidency Conclusions, 1999, http://europe.eu.int/council/off/conclu/index.htm

${ }^{69}$ Leaken European Council Presidency Conclusions, 2001, http://europe.eu.int/council/off/conclu/index.htm

${ }^{70}$ Buvo pasirašytos prekybos ir komercinio bei ekonominio bendradarbiavimo sutartys, kurios vẻliau šalims kandidatėms perkeltos i aukštesnị lygmeni - Europos sutartis. 1995 m. Paryžiuje pasirašytas Europos stabilumo paktas, kurio tikslas buvo skatinti vidurio ir rytų Europos šalių tarpusavio bendradarbiavimą bei dialogą su vakarų valstybėmis.
} 
verte pietines ES šalis siekti bendros prevencinės strategijos, skirtos užkirsti kelią nepageidaujamoms šiu procesų pasekmėms. 1995 m. Barselonoje buvo įkurta ES Viduržemio jūros taryba, skirta plètoti bendradarbiavimą tarp ES ir šio regiono valstybių. Iniciatyvoje dalyvavusios valstybès ${ }^{71}$ pasirašè susitarimą, numatantị bendradarbiavima karinëje, ekonominėje, finansinėje, kultūrinëje ir kitose srityse. Siekdamos užtikrinti stabilumą regione, ES valstybès narès taip pat nusprendè, kad vieningos Europos kūrimas yra atviras procesas ir prieinamas visoms Europos tautoms, turinčioms tokius pačius interesus bei tikslus tuo pradėdamos plètros procesą ${ }^{72}$. Sajungos plètrą galima vertinti kaip svarbų veiksni, formuojant saugų ir stabilų Europos regioną.

Atsižvelgiant ị tai, kad ES vykdomos saugumo užtikrinimo priemonès vis plečiasi, o veikla apima visus saugumo žiedus, galima teigti, kad BSGP turi puikias perspektyvas tapti svariu Europos kooperacinio saugumo sistemos ramsčiu, tačiau šios perspektyvos priklausys nuo to, ar ES pavyks išspręsti problemas, susijusias su vidiniais organizacijos aspektais, jos santykiais su valstybėmis ne ES narèmis bei kitomis tarptautinemis organizacijomis.

Kiolno, Helsinkio bei vėlesniųų ES viršūnių tarybų sprendimai įpareigojo ES valstybes nares dalyvauti bendruose kariniuose veiksmuose, vykdant ne 5 str. pobūdžio Petersbergo užduočių operacijas. Miglotas Petersbergo užduočių apibrěžimas sąlygoja dvi problemas: teritorinio ịsipareigojimo ir būsimų operacijų neapibrèžtumo. ES gynybinių pajègumų panaudojimo scenarijai svarstomi jau nuo $1995 \mathrm{~m}$., o galimų operacijų nuotolis nuo Briuselio apibrěžiamas „nuo 2000 iki 6000 km“. Tai reiškia, kad trumpiausio nuotolio operacijos nesieks išsiplètusios ES rytinių sienų, o tolimiausios operacijos gali vykti Afganistane, Viduriniojoje Azijoje ar net Demokratinejje Kongo respublikoje ${ }^{73}$. Petersbergo užduotys pagal dabartini apibrèžimą gali įtraukti net tokius didelio masto konfliktus kaip Įlankos karas. Tik išsprendus apibrěžimo problemas, galima nustatyti, kiek ir kokio pobūdžio pajègos ES bus reikalingos ir kokia institucinè struktūra tinkamiausia veiklos koordinavimui.

Verta paminèti, kad lygiagrečiai su ES reformomis vykstantis plètros procesas neišvengiamai veiks tolimesnị BSGP vystymąsi. Galima išskirti du plètros įtakos akcentus: finansinès problemos, kylančios visų pirma dẻl pertvarkų ES viduje ir, antra, dèl naujų ekonomiškai silpnesnių narių įsijungimo bei stabilumo problemos, atsirandančios dèl išsiplètusios ES geografijos. Per greitas plètros procesas gali susilpninti ES institucinę galią bei ekonominị ir politinị stabilumą. Taigi išorinių saugumo problemų sprendimas, integruojant ị Sajungą nestabilius Europos regionus, iškèlẻ naujo pobūdžio pavojus, susijusius su vidaus saugumu (nusikalstamumo migracija, ekonominis bei socialinis atotrūkis, bei su juo susiję konfliktai ir t.t). Tankų bei raketų, atvykstančių iš už „,geležinės uždangos“, baimę pakeité nekontroliuojamos migracijos ir tarptautinio nusikalstamumo grèsmès ${ }^{74}$. Dauguma kandidačių susiduria su ekonominèmis problemomis, o demokratija jose nèra tokia stabili, kaip anksčiau buvo ịsivaizduojama ${ }^{75}$. Problematiška ir tai, kad plètra Sajungos sienas perkelia

\footnotetext{
${ }^{71}$ Susitarimą pasirašė ES ir Alžyras, Kipras, Egiptas, Izraelis, Jordanija, Libanas, Malta, Marokas, Sirija, Tunisas, Turkija bei Palestinos vadovybè. Keatinge, (note 33), 19.

${ }^{72}$ Los Nowak. T., „Euroregions as an European Identity creating factor: premises, possibilities, jeopardies“, Copri papers, http://www.copri.dk/copri/downloads/25-2000.doc

${ }^{73}$ Croft, (note 61), 102.

${ }^{74}$ Grabbe H., „The Sharp Edges of Europe: Security Implications of Extending EU Borders Policies Eastwards“, Occasional Paper No. 13, 2000, 7.

${ }^{75}$ Winn, (note 34), 79.
} 
arčiau nestabilių regionų. Lenkijos, Slovakijos ir Lietuvos įstojimas priartins Ukrainą ir Baltarusiją, Kipro narystė lems tiesioginį sąlytį su Viduriniaisiais Rytais. Turkijai ịstojus, ES kaimynèmis taptų Sirija, Iranas bei Irakas. ES geografinių ribų išsiplètimas gali įvelti valstybes nares į ilgalaikius bei brangiai kainuojančius konfliktus su nestabiliais naujais „kaimynais“ ir neigiamai veikti Europos saugumą.

BSGP efektyvumas neabejotinai priklausys nuo to, ar ES sugebès greitai ir veiksmingai kovoti su neprognozuojamomis krizėmis. ES taikomų priemonių operatyvumą gali sumažinti antrame ramstyje įtvirtinti tarpvyriausybiškumo ir vienbalsiškumo principai. Dauguma saugumo analitikų pripažista, kad veiksmingas BSGP įmanomas tik tais atvejais, jei europiečiai įtvirtins daugumos balsavimo procedūrą bei viršvalstybiškumo principą arba jei viena šalis (ar kelios) imsis vadovaujančio vaidmens. Deja, toks ES vystymosi scenarijus bent jau artimoje ateityje mažai tikètinas. Siekiant panaikinti bent dali šių principų sąlygojamų kliūčių, Nicos sutartyje buvo numatyta konstruktyvaus susilaikymo galimybe $\dot{e}^{76}$. Konstruktyvaus susilaikymo principas garantuoja valstybei narei teisę susilaikyti, balsuojant dèl iniciatyvų, kuriose šalis nepageidauja dalyvauti, neblokuojant sprendimo prièmimo. Susilaikiusiujų skaičius neturi viršyti trečdalio narių skaičiaus. Nicos sutartis numate glaudesnio bendradarbiavimo principą (angl. enhanced co-operation), sudarydama sąlygas valstybių grupèms siekti gilesnès integracijos užsienio ir saugumo politikoje, neegzistuojant sutarimo kitose srityse. Vis délto baiminamasi, kad Nicos sprendimai suteikè per daug galių kelioms ịtakingoms valstybėms bei ES biurokratams ir skatina ES fragmentaciją, kuri savo ruožtu gali mažinti BSGP efektyvumą.

Viena iš svarbiausių BSGP problemų - tai karinių pajėgumų problema, kuri ypatingai išryškėjo Balkanuose. Buvusio JAV Gynybos sekretoriaus ir generolo Henrio Scheltono Senato Ginkluotujų pajęgų komitetui pateiktame pranešime Europos sajungininkų veikla Kosove buvo įvertinta nepalankiai ${ }^{77}$. Amerikiečiai reziumavo, kad europiečiai susiduria su dideliais sunkumais karinių pajègų mobilumo, vadovavimo, kontrolèje ir komunikacijos srityse. Balkanų konfliktai išryškino trūkumus strateginejje žvalgyboje, priešraketinėje gynyboje, oro perkẻlime, tikslaus valdymo raketų bei kitose sferose, kurios susijusiose su moderniomis technologijomis. Europiečiams nepavyko užtikrinti netgi reikalingo karių skaičiaus bei ịprastinès ginkluotès.

Europos karinių resursų trūkumas - tai nepakankamo finansavimo ir neteisingo lěšų paskirstymo pasekmè, sunkinanti ne tik europiečių galimybes veikti savarankiškai, bet ir bendradarbiauti su JAV. $2000 \mathrm{~m}$. JAV karinès išlaidos buvo 296373 mln. JAV dolerių ir sudare 3\% BNP, o Europos sajungininkų bendros karinès išlaidos tesieke $164559 \mathrm{mln}$. JAV dolerius ir 2,1\% $\mathrm{BNP}^{78}$. Nors aštuonios iš ES NATO narių $2001 \mathrm{~m}$. padidino savo karines išlaidas ${ }^{79}$, europiečių lěšos nebuvo tinkamai naudojamos. Daugiausia gynybos reikmėms skiriamų pinigų naudojama perkrautoms bei technologiškai nuo amerikiečiu atsiliekančioms kariuomenèms finansuoti, o didžioji dalis amerikiečių karinių išlaidų yra skiriamos investicijoms ị modernias technologijas. Sunku ịvertinti ES sugebejjimus užtikrinti BSGP reikalingą finansavimą. Tik Pagrindinio tikslo ịsipareigojimų igyvendinimas pareikalaus maždaug kelių

\footnotetext{
${ }^{76}$ Treaty of Nice, Brussels, 14 February 2001, SN1247/1/01 REV1. Art.24 (3).

${ }^{77}$ Smith I. D., „Evidence to the Committee on International Relations, House of Representatives“, Wednesday 10th November, 1999.

${ }^{78}$ NATO Handbook, Brussels: NATO Office of Information and Press, 2001.

${ }^{79}$ Grant Ch., „A European view of ESDP“, http://www.eusec.org/grant.htm
} 
milijardų JAV dolerių kiekvienais metais. Minètina ir tai, kad nustatydami pagrindinị tikslą europiečiai blogai apskaičiavo realias jo įgyvendinimo galimybes, nes šio tikslo igyvendinimui dèl karių atrankos ir rotacijos reikès ne 50 000-60 000 karių, o apie 200 000-230 000. Atitinkamai išaugs ir jų aptarnavimui reikalingos karinès technikos, logistikos bei kt. papildomu pajegumų apimtys. Mažai tikètina, kad ši problema bus išspręsta, kol ES nepadidins savo gynybos išlaidų ir nepakeis jų skirstymo strategijos.

Didžiausias kariuomenes ES turi Vokietija, Graikija ir Italija. Jų pajegos 760000 karių sudaro daugiau nei 55\% JAV kariuomenès, tačiau ginkluotei šios šalys išleidžia tik $10 \%$ amerikiečių šioms reikmèms skiriamų lėšų ${ }^{80}$. ES išlaidos moksliniams tyrimams sudaro apie ketvirtadalį amerikiečių lěšų ir iš esmès tai - Didžiosios Britanijos bei Prancūzijos pinigai.

Tarptautinių strateginių studijų instituto duomenimis, per kitą dešimtmetį Europai reikètų maždaug $35 \mathrm{mlrd}$. JAV dolerių vien tam, kad sumažintų prarają tarp ES ir JAV ginkluotuju pajègų. Tačiau ES šalys nenori smarkiai didinti savo gynybos biudžetų. 2002 metais JAV gynybai numate išleisti apie 3,7\% BVP, ES vidurkis nesieke 2\% BVP. Akivaizdu, kad atotrūkis tarp Europos ir JAV karinių resursų bent jau artimoje ateityje tik dides ir tai gali tapti rimta problema ne tik BSGP, bet ir NATO efektyvumui, taip pat neigiamai veiktų viso Europos regiono saugumą bei stabilumą. Nors Europos politikai teigia, kad ES ịsipareigojimai nèra tokio globalaus pobūdžio kaip JAV (Azijoje ir Viduriniuosiuose Rytuose), todèl misijoms vykdyti nereikès tiek resursų ir lèšų, kiek reikia JAV, verta atkreipti dèmesị i tai, kad ES sienoms išsiplètus ị ,nestabilius regionus", siekdama apginti savo nares bei jų interesus, ES gali būti priversta dalyvauti misijose, kurios pareikalaus didelių resursų. Antra vertus, dẻl nepakankamo ir neteisingo karinių pajègų finansavimo, sąlygojančio jų atsilikimą, europiečiai gali nesugebèti dalyvauti bendrose misijose kartu su amerikiečiais. Trečia, Europos pajègoms dalyvaujant kariniuose veiksmuose su amerikiečiais reikès išspręsti ir veiksmų bei išteklių koordinavimo klausimus. 1996 m. Berlyno Komunikatas numatė VES ,priejjimą" prie NATO karinių pajėgumų, kuris buvo patvirtintas „Berlin plus“ formule ${ }^{81}$. NATO-ES bendradarbiavimas buvo dar kartą patvirtintas Kopenhagos viršūnių tarybos susitikime, tačiau nei Berlyno Komunikatas, nei nauji susitarimai neišspręs europiečių pajėgumų problemos, kai JAV resursai bus reikalingi kovai su globaliomis grèsmėmis.

Siekiant sumažinti atotrūkị tarp JAV ir ES šalių karinių pajëgumų bei pritaikyti ES karinius dalinius lankstumo bei mobilumo reikalaujančiai veiklai, ES šalyse vyko karinių pajègų reformos: Prancūzijoje -1994-1996 m., Vokietijoje - 1994-2000 m., Švedijoje - 1995-1999 m., Didžiojoje Britanijoje - 1993-1998 m. ${ }^{82}$ Pagrindinis reformų tikslas buvo sukurti negausias, bet profesionalias ir moderniai ginkluotas

\footnotetext{
${ }^{80}$ Heisbourg F., „European Defence Takes a Leap Forward“, NATO Review, 48 (1), 2000, 97.

${ }^{81} 1996$ m. Berlyne buvo priimti sprendimai suteikti NATO paramą VES vadovaujamoms operacijoms (Berlyno Komunikatas). 1999 m. šis susitarimas buvo patobulintas „Berlin plus“ formule. „Berlin plus“ paketas įtraukè 4 elementus: 1) užtikrino ES „priejimą“ prie NATO operacijų planavimo; 2) numate ES galimybę naudotis NATO pajègumais; 3) patvirtino NATO Europos vadovavimo struktūrų panaudojimo ES vadovaujamose operacijose galimybę (îskaitant Sajungininkų pajègų Europoje vyriausiojo vado (SACEUR) dalyvavimą); 4) įsipareigojo pritaikyti NATO gynybos sistemą, ittraukiant ES operacijoms skirtas pajëgas, http://www.nato.int/uk.docu/esdi.htm

${ }^{82}$ Andersson J. J., „Cold War Dinosours or Hi-Tech Arms Providers? The West European Land Armaments Industry at the Turn of the Millenium“, Occasional Paper No. 23, 2001, 6.
} 
karines pajėgas: užtikrinti armijos profesionalumą, atsisakyti priklausomybės nuo šauktinių (kurių pagal daugumos ES šalių įstatymus teisiškai negalima dislokuoti už ES ribų), padidinti krizių valdymui skirtų karinių pajègų kiekį bei aprūpinti jas modernia ginkluote. Prancūzai jau nuo $2002 \mathrm{~m}$. turi profesionalią kariuomenę. Didžiosios Britanijos, Belgijos, Nyderlandų bei Liuksemburgo karines pajegos yra visiškai profesionalizuotos. Šauktinių skaičių ženkliai sumažino ispanai ir italai. Reformos vyksta ir kitose ES šalyse ${ }^{83}$. Jau beveik prieš dešimtmetị prasidèjusių reformų rezultatus jau galima apčiuopti. $2002 \mathrm{~m}$. Europos valstybės skyrè $60 \%$ visų 20000 pajęgų misijoje Bosnijoje ir 37000 Kosove, kai JAV teskyrè atitinkamai $20 \%$ ir $25 \%$. Europos pajegu veikla šiose misijose buvo įvertinta labai teigiamai ${ }^{84}$. Kopenhagoje ES ịsipareigojo galutinai perimti iš NATO taikos palaikymo užduotis Bosnijoje ir Makedonijoje. Taigi nežiūrint vis dar didelių karinių pajėgumų trūkumų, europiečių karinės pajëgos sugeba susidoroti su kai kuriais šiandieninio pasaulio iššūkiais.

Karinių pajëgumų problemos neišvengiamai siejasi su Europos karinès pramonès problemomis, kylančių dẻl fragmentuotos karinės pramonės struktūrų, konkuruojančiu interesų bei rinkos nepakankamumo. Ir nors šioje srityje galima pastebèti pozityvių kaitos tendencijų - $2002 \mathrm{~m}$. Britanija, Prancūzija, Vokietija ir Italija įsteigė Bendrą organizaciją bendradarbiavimui ginkluotės srityje (OCCAR), igyvendinsiančią bendras pirkimų programas bei igalintą sudaryti bendrus kontaktus; Ispanija ir Švedija 1998 m. pasirašè ketinimų protokolą, skirtą koordinuoti ir derinti kai kurias gynybos politikos sritis bei procedūras; jungiasi didžiausios Europos karinès pramonès kompanijos (EADS, BAE Systems) - europiečiai vis dar nesugeba konkuruoti su amerikiečiais.

Efektyvi Europos kooperacinio saugumo sistema ir veiksminga BSGP neįmanomos be Rusijos. Europos saugumas priklauso tiek nuo Rusijos užsienio politikos, tiek nuo jos viduje vykstančių demokratizacijos procesų ir perèjimo prie rinkos ekonomikos rezultatų. JAV savo karinius resursus nukreipus globalių problemų sprendimui, europiečiams gali būti sunku vieniems susidoroti su regioninio pobūdžio grèsmėmis. Europiečiu partnere, kovojant su postmoderniomis regioninèmis grèsmėmis, galètų tapti Rusija ${ }^{85}$. Bendradarbiavimo saugumo bei gynybos srityje svarbą pripažino tiek ES, tiek Rusijos politikai ir tai įrodo suintensyveję Rusijos-ES santykiai, kurie paskutiniaisiais metais perejo ị kitą lygmenị. Jeigu anksčiau rusai su atskiromis ES valstybėmis buvo linkę bendradarbiauti dvišaliais santykiais, tai dabar Rusija su ES vis dažniau bendradarbiauja kaip su vieninga organizacija. $2000 \mathrm{~m}$. spalio mèn. vykusio ES-Rusijos viršūnių susitikimo metu, ES pareiškè, kad yra linkusi stiprinti dialogą ir bendradarbiavimą saugumo ir gynybos klausimais. Susitikimo dalyviai nutare sukurti specialias konsultacijas šiais klausimais, plètoti strateginị dialogą aktualiais Rusijai ir ES saugumo klausimais, plèsti konsultacijų spektrą nusiginklavimo, ginkluotès kontrolès ir ginklų neplatinimo klausimais bei plètoti bendradarbiavimą krizių valdymo srityje. Naujausios bendradarbiavimo iniciatyvos apima kovos prieš terorizmą, organizuotą nusikalstamumą, masinio naikinimo ginklus klausimus.

Bendradarbiavimas tarp ES ir Rusijos vyksta ir gynybos pramonės srityje. Kosmoso bei palydovinès technikos pasaulyje, palyginus su JAV ir Rusija, europiečiai ịsitvirtino pakankami vẻlai. Iki $2000 \mathrm{~m}$. Europos koncernų susijungimo į EADS nebuvo jokių didelio masto programų bei infrastruktūrinio pagrindo. $2001 \mathrm{~m}$. EADS

\footnotetext{
${ }^{83}$ Grant, (note 79).

${ }^{84}$ Lindley-French, (note19) 10.

${ }^{85}$ Kremenyuk (note 22 ).
} 
kartu su Rusijos oro erdvès ir kosmonautikos agentūra susitarè sujungti resursus, igyvendinant konkrečius projektus.

Vis dèlto tolimesniam ir glaudesniam bendradarbiavimui būtina Rusijos politinè valia, karinių struktūrų reformos tiek technologine, tiek ideologine prasme bei esminiai pokyčiai karinejje pramonėje. Rusijos ir ES galimybės veikti kartu priklausys tiek nuo Rusijos ir ES vidaus problemų sprendimo, tiek nuo to, kokị vaidmeni Europos saugume europiečiai skirs Rusijai: ar ji taps lygiaverte ES partnere, ar jai teks tik ,jaunesniojo brolio“vaidmuo.

Po rugsejjo 11-osios dažnai sakoma, kad BSGP prarado savo svarbą, tačiau šis teiginys nėra pagrịstas. Pirma, sėkmingas BSGP vystymasis padètų amerikiečiams sutelkti visą dèmesi i i kovą su terorizmu. Antra, BSGP kompetencijai priklausančių Petersbergo užduočių reikšmė po rugsèjo 11-osios nesumažèjo, o išaugo. ES greito reagavimo pajègos galètų būti naudojamos ir kovai su globalaus pobūdžio grèsmèmis. Praëjus dešimčiai dienų po teroristinių išpuolių Europos viršūnių taryba ir BUSP igaliotasis atstovas Javieras Solana patvirtino kovos prieš terorizmą programą ${ }^{86}$. Šis žingsnis rodo, kad organizacija reaguoja į saugumo pokyčius tarptautineje aplinkoje. ES antiteroristinè programa įtraukusi platų kovos priemonių spektrą (ypač teisingumo ir žvalgybos srityse) dar paskatino BUSP ir BSGP vystymąsi ${ }^{87}$. Deja, politinèje sferoje ES narès kol kas yra linkusios veikti ne ES institucijose, o vienašališkai.

Nors BSGP galimybes Europos kooperacinio saugumo sistemoje vis dar sudètinga įvertinti, galima teigti, kad jos priklausys nuo to, ar ES pasiseks išspręsti Petersbergo užduočių neapibrèžtumo, tarpvyriausybiškumo bei vienbalsiškumo, karinių pajėgumų nepakankamumo problemas. Kita vertus, BSGP likimą neabejotinai veiks ir ES bendradarbiavimo su NATO, JAV bei Rusija intensyvumas ir kokybė.

\section{Išvados}

Pokyčiai tarptautinėje sistemoje ir saugumo problematikoje skatina susimąstyti, ar naujai besiformuojančiame pasaulyje Europa bus saugi ir kas galètų užtikrinti šio regiono saugumą? Atlikus bendrų saugumo problematikos pokyčių analizę ir įvertinus pagrindines daugiašales Europos regiono saugumo iniciatyvas, galima teigti, kad globaliu mastu Europos saugumas priklausys nuo bendrų centro valstybių pastangų sumažinti neigiamas globalizacijos pasekmes, centro bendradarbiavimo su periferijos valstybėmis politineje, ekonominèje ir saugumo srityse, taip pat nuo atskirų Europos šalių, Rusijos bei JAV elgesio racionalumo ir nuoseklumo. Karinejje plotmèje vienu iš svarbiausių Europos valstybių tikslų turètų tapti transatlantinio ryšio stiprinimas. Tikètina, kad Europos saugumui gyvybiškai svarbus bendradarbiavimas tarp ES ir JAV saugumo srityje išliks ir toliau vyks funkcijų pasidalijimo pagrindu, išnaudojant privalumus srityse, kuriose šalys turi geriausią potencialą. Sio funkcijų pasidalijimo pagrindu dviejuose lygmenyse (Europa ir JAV), ko gero, vyks ir bendradarbiavimas su Rusija. Rusijos bei Europos šalių saugumo santykiai apims sritis, kuriose ES bus kompetetinga - „lengvojo“"saugumo klausimus bei regionines bendradarbiavimo iniciatyvas.

${ }_{86}$ European Council (JHA) Conclusions, Brussels, 20 Sept. 2001, SN 3926/6/01 Rev. 6, 20 Sep, 2001.

${ }^{87}$ Rotfeld (note 45), 9. 
Regioniniame lygmenyje Europos saugumą veiks tiek šiam regionui tik iš dalies priklausančiu valstybių (JAV ir Rusija) vaidmuo regioninejje saugumo sistemoje, tiek pačių europiečių tarpusavio bendradarbiavimo sẻkmè. Šiandieninės Europos saugumą efektyviausiai užtikrintų kooperacinio saugumo sistema, besiremianti valstybių ar daugiašalių institucijų bendradarbiavimu ir sujungianti tarpusavyje susijusius individualaus, kolektyvinio, išorinio (stabilumo plètra) saugumo ir kolektyvinès gynybos žiedus.

Europos saugumo sistemos sékmė priklausys nuo, pirma, pagrindinių Europos saugumo institucijų, ES ir NATO, veiklos koordinuotumo bei efektyvumo. Antra, ją neišvengiamai veiks NATO modernizacijos bei pletros rezultatai, susiję su NATO struktūros reformomis, 5-ojo str. problemos sprendimu, JAV-NATO-ES bendradarbiavimo koordinavimu ir tarpusavio santykiu gerinimu, plètros proceso sąlygotų problemų sprendimu bei bendradarbiavimo struktūrų su valstybemis ne narėmis vystymu. Trečia, efektyviai Europos kooperacinio saugumo sistemai ypatingai svarbi bus tolimesnẻ BSGP evoliucija bei Petersbergo užduočių neapibrěžtumo problemos sprendimas, tarpvyriausybiškumo ir vienbalsiškumo principų panaikinimas arba jų „švelninimas“ ir kariniu pajęgumų didinimas bei tobulinimas. BSGP perspektyvas neabejotinai veiks ir ES bendradarbiavimo su Rusija intensyvumas bei kokybè.

Europos saugumo institucijos, besitaikydamos prie XXI a. saugumo aktualiju pasikeite tiek išoriškai, tiek iš vidaus ir tai leidžia, kad besiformuojanti Europos kooperacinio saugumo sistema, nors dar netobula, ateityje sugebės efektyviai užtikrinti Europos saugumą regioniniu mastu. Nors kol kas per daug optimistiška būtų prognozuoti, kad tokia sistema galètų veikti ir globalioje plotmėje, kurioje dar gausu nedemokratinių, nestabilių periferijos veikèjų, gyvenančių pagal visiškai kitus principus nei to reikalauja kooperacinès saugumo sistemos kriterijai. Vis dèlto ị ilgalaikes bendradarbiavimo struktūras galima ijungti ne visas valstybes. Šalia visoms valstybẻms bendrų interesų - užtikrinti šalies suverenitetą ir teritorinį integralumą - ilgą laiką kooperacinio saugumo sistemoje dalyvaujančios valstybės turi kitų tikslų, kurie sietini su šalies piliečiais, gerove, ekonomika, ekologija, kultūra, teise bei globalesnio pobūdžio vertybėmis: pagarba žmogaus teisèms, teisinei tvarkai ir demokratijai. Tikètina, kad Europos kooperacinio saugumo sistemos pagrindu vykstantis bendradarbiavimas, keisdamas saugumo santykių taisykles, elgesio normas, interesus ir net bendrą saugumo suvokimą, ilguoju periodu gali peraugti i globalesnị lygmenį. 